\title{
Childbearing Within Marriage and \\ Consensual Union in Latin America, 1980-2010
}

\author{
Benoît Laplante \\ Professor, Institut national de la recherche scientifique, Université du Québec, Canada.
}

Teresa Castro-Martín

Research Professor, Spanish National Research Council.

Clara Cortina

Assistant Professor, Universitat Pompeu Fabra, Spain.

Teresa Martín-García

Researcher, Spanish National Research Council.

\footnotetext{
${ }^{1}$ This is an early draft of an article that has subsequently been published in Population and Development Review. Complete citation information for the final version of the paper, as published in the print edition of Population and Development Review, is available on Wiley Interscience's online journal service, accessible via the journal's website at http://www.blackwellpublishing.com/pdr.
} 


\begin{abstract}
This article compares the fertility patterns of women in consensual union and marriage in 13 Latin American countries, using census microdata from the four most recent census rounds and a methodological approach that combines the own-children method and Poisson regression. Results show that in all these countries, fertility is slightly higher within consensual union than marriage and that the age pattern of fertility is very similar in marital and non-marital unions. Further analyses show that over the period considered, childbearing within a consensual union has passed from rare to increasingly common, although not yet mainstream, for highly educated women in most countries examined. Results show that in Latin America, at least since the 1980s, women's childbearing patterns depend on their age and on their being in a conjugal relationship, but not on the legal nature of this relationship. The similarities in reproductive behavior between marital and non-marital unions are not confined to the socially disadvantaged groups, but apply as well to the better off.
\end{abstract}

\title{
Keywords
}

Nuptiality, family formation, marriage, cohabitation, consensual union, non-marital fertility, census microdata, IPUMS, Own Children Method, Poisson regression, Latin America 


\section{Childbearing Within Marriage and \\ Consensual Union in Latin America, 1980-2010}

One of the most salient demographic features of Latin America is its dual nuptiality regime (CastroMartín 2002). Marriages and consensual unions coexist side by side in all countries of the region, although the prevalence of consensual unions varies significantly from country to country - from about $20 \%$ of all conjugal unions among women aged 15 to 49 in Chile up to $74 \%$ in the Dominican Republic (Castro-Martín et al. 2011) — as well as across regions within the same country (Esteve, Lesthaeghe and López-Gay 2012) and across social classes (Arriagada 2002).

Both forms of conjugal union have achieved similar levels of social acceptance, but they often differ in terms of stability, legal obligations, and economic rights after breakdown (Quilodrán 1999; De Vos 2000; Castro-Martín 2002; Rodríguez Vignoli 2004). Unlike what occurred in the developed world, where cohabitation did not achieve social — and statistical_visibility until the 1980s, consensual unions have been an integral part of the family system in Latin America for centuries (Socolow 2000). Furthermore, whereas in North America and many European countries cohabitation is often a transitional stage leading to marriage, in Latin America the prevalence of consensual unions remains high in later stages of the life course, suggesting that they are often regarded as a functional alternative to marriage. Nevertheless, the most notable difference is that, whereas in North America and Europe — with several exceptions such as the Nordic countries, France or Quebec — cohabitation tends to be a childless stage, in Latin America it is a common family arrangement for bearing and raising children. This feature blurs the differences between de jure unions and de facto unions. According to a recent study, in the Latin American region, the proportion of births from lone mothers rose from $7 \%$ to $15 \%$ from 1970 to 2000 , and the proportion of births that took place within a consensual union rose from $17 \%$ to $39 \%$ (Castro-Martín et al. 2011). In the $21^{\text {st }}$ century Latin America, hence, more children are born outside than within marriage.

This new setting is what has motivated this study. We wish to explore further the similarities and differences in the reproductive behavior of married women and women living in a consensual union. We know that for many Latin American women, marriage is not a prerequisite for having children, but we aim to measure more precisely the differences in fertility patterns of formal and informal unions over the reproductive age range. We also want to explore whether these fertility patterns by 
union type are equivalent across women with different levels of education, which we use as a proxy of social and economic resources and opportunities as well as relative position in the social hierarchy.

In the European and North-American literature, cohabitation and childbearing within cohabitation have been usually discussed from the perspective of the Second Demographic Transition (Seltzer 2000; Kiernan 2001; Sobotka and Toulemon 2008). The spread of cohabitation is regarded as a consequence of secularization trends, rising expectations of personal autonomy, rejection of Church and State intervention in the regulation of private life, and growing importance of personal satisfaction within the couple relationship (Lesthaeghe 2010). Recent studies have also shown that cohabitation in some countries can be also related to socioeconomic disadvantage, and used as an alternative to marriage by people with few economic resources or poor economic expectations (Goldstein and Kenney 2012; Kiernan et al. 2011)

In Latin America, consensual unions have traditionally been common among underprivileged social sectors and in rural areas - leading to it being dubbed the "poor people marriage"-, while they were very rare among the upper class. This pattern suggests that initiating the family formation process within a consensual union rather than a marriage might not always be the result of personal choice but, at least in part, the consequence of limited economic and social opportunities (Greene 1991; Castro-Martín 2001; García and Rojas 2004). However, an important change in nuptiality patterns has occurred over the last two decades. The presence of consensual unions had started to become noticeable among the well-educated and in urban areas by the end of the 1990s (Parrado and Tienda 1997). This presence is more manifest and better documented in the Southern Cone (Cabella, Peri, and Street 2005; Cabella 2009; Laplante and Street 2009; Binstock 2010). Other studies have shown that the recent rise in unmarried cohabitation has encompassed all educational groups, not just the underprivileged (Castro-Martín, Martín-García, and Puga González 2008; Quilodrán 2011). According to data from the 2000 census round, a significant proportion of Latin American universityeducated women aged 25 to 29 and living in a conjugal union are cohabiting rather than being married, the proportion exceeding 30 percent in Argentina, Colombia, Cuba, and Peru (Esteve, Lesthaeghe, and López-Gay 2012).

The fact that cohabitation has recently disseminated among the middle and upper class has led researchers to make a distinction between "traditional" and "modern" consensual unions (Quilodrán 2011). "Traditional" consensual unions, still the most common in all Latin-American countries, are generally associated to cultural heritage, limited economic opportunities, and asymmetrical gender 
relations. By contrast, "modern" consensual unions, still in an emerging stage, are considered as the result of a conscious choice in the pursuit of individual autonomy, freedom from institutional control, and less asymmetry between the genders, pretty much along the lines of the Second Demographic Transition (Lesthaeghe 1995, 2010; Billari and Liefbroer 2004).

Yet there is no complete consensus on the underlying causes and proper interpretation of the more recent expansion of cohabitation in Latin America. Some researchers consider that it should be attributed to modernity and the advance of the Second Demographic Transition in the region (Esteve, Lesthaeghe, and López-Gay 2012). Other researchers point at additional catalysts, such as the increasing uncertainty that the middle class is now confronted with in their working, social, and family life (García and Rojas 2004; Arriagada 2007; Quilodrán and Castro-Martín 2009). Moreover, there are large differences not only in the prevalence of cohabitation, but also in its social meaning, symbolic value, motivation, and consequences, across countries, social classes, and ethnic groups (Covre-Sussai et al. 2014). In many indigenous communities, lack of a marriage certificate is deemed irrelevant and does not lead to family instability, whereas in the poorest social segments, it is commonly a sign of precariousness, exclusion, and vulnerability. In the middle and upper classes, it is not clear whether the emerging form of cohabitation is a step in the union formation process that precedes formalization, or it is an alternative to marriage and hence a family arrangement in which children will be born and raised (CEPAL 2002).

This article is an attempt to further our understanding of the process of family formation outside of marriage in Latin America. Comparing the reproductive behavior of cohabiting and married women constitutes a promising avenue for understanding how consensual unions fit into the family system (Raley 2001). Recent research has shown an important change in the socioeconomic profile of consensual couples in the region, due to the recent uptake of cohabitation by higher educated young adults (Esteve, Lesthaeghe, and López-Gay 2012). Our main objective is to find whether there is a similar change in the socioeconomic profile of childbearing within cohabitation. By comparing the reproductive patterns of married women and consensually partnered women, we should be in a better position to ascertain whether consensual unions are short-lived couple relationships, trial marriages, "poor people marriages," or long-lasting alternatives to marriage. We should also be able to explore the diversity in meanings of cohabitation across Latin-American societies and across social classes. We are particularly interested in ascertaining whether the emergent pattern of cohabitation among the middle and upper class corresponds to a trial marriage, where children are 
postponed until the relationship is formalized, or to an alternative to marriage, where children are typically born and raised, as it has traditionally happened in the disadvantaged groups.

\section{The prevalence of cohabitation and births within cohabitation in Latin America}

In Latin America, consensual unions have been part of the family system for centuries and nowadays they coexist side by side with marriage configuring the distinct nuptiality system of the region (Castro-Martín 2002). Notwithstanding their key role in the family formation process, the prevalence of consensual unions varies considerably across Latin American societies. In countries such as the Dominican Republic, Panama, Honduras, Nicaragua, Peru, Colombia, and Uruguay-listed in descending order of prevalence-, the proportion of consensual unions even surpasses that of marriages among women in union of reproductive age (see Table 1). The Dominican Republic is the country with the highest prevalence of consensual unions: three out of four women aged 15 to 49 currently in union live in an informal union. Cuba, El Salvador, Venezuela, Ecuador, Brazil, and Paraguay also have a relatively high prevalence of consensual unions among partnered women of reproductive age, ranging from $49 \%$ to $40 \%$. The lowest prevalence in the region is currently observed in Chile, where only one-fifth of the unions are consensual, but this level is based on the 2002 census and the still unreleased data from the 2012 census might show an increase.

[Table 1 about here]

According to vital statistics, the number and proportion of non-marital births are remarkably high in most countries of the region. In the 2000s, the proportion of births from unmarried women was higher than that from married women in all Latin American countries for which data are available (see Table 2). In some countries, such as the Dominican Republic, Venezuela, Cuba, and Panama, the proportion of non-marital births reaches four-fifths of all births. In some countries for which trend data are available, such as Panama or El Salvador, the proportion of births to unmarried mothers was already very high in the 1970s. In the rest of the countries, there has been a remarkable increase.

[Table 2 about here]

However, vital statistics in many Latin American countries suffer from under-registration (Harbitz, Benítez Molina, and Arcos Axt 2010) and, with few exceptions such as Costa Rica, do not 
provide information on whether or not the unmarried parents are living together, so children born from a mother living in a consensual union are not reported separately from those born from a mother who does not have a co-residential partner.

In order to distinguish births from cohabiting mothers and lone mothers, one needs to resort to census data or surveys with retrospective birth histories. However, the latter are not widely available for Latin American countries. A recent analysis based on census microdata for 13 Latin American countries documents that there has been a considerable increase in the proportion of births outside marriage over the last decades, and that most of this rise is concentrated in cohabiting unions (CastroMartín et al. 2011). Table 3 illustrates the changing distribution of births in the region according to the conjugal status of the mother from 1970 to 2000 . The dramatic decline in the percentage of births within marriage over the whole period (from three-quarters to just nearly one-half) goes in parallel with the significant rise in births from women in consensual unions (from 16.8\% to 38.9\%). Data show that the percentage of births from lone mothers has also increased, but more modestly (from $7.3 \%$ to $15 \%$ ). In other words, the fact that non-marital births have surpassed marital births since the beginning of this century in Latin America is mainly due to the increase in births from parents in consensual union.

[Table 3 about here]

\section{Data}

We use data from the IPUMS collection of harmonized census microdata files from the four most recent census rounds available (Minnesota Population Center 2013). Census data contain reliable information on the current conjugal situation of all individuals (Rodríguez Vignoli 2011) and provide a workable alternative to vital statistics or biographical surveys when used with the own-children method of fertility estimation. We focus on 13 Latin American countries for which such data are available: Argentina, Bolivia, Brazil, Chile, Colombia, Costa Rica, Cuba, Ecuador, Mexico, Panama, Peru, Uruguay, and Venezuela. Depending on the country, between one and four censuses were available and included the information we needed.

Although access to comparable census data for a large number of countries covering four decades is a major advantage, census data also have important drawbacks. First, data pertain only to women's current union status and not to union status when giving birth; second, dates of entry into 
union are not reported, and hence no union durations can be computed. To minimize possible bias we focus our analysis on births born in the year prior to the census.

\section{Methods}

We compare the fertility of women in consensual union and marriage estimating age-specific fertility rates (ASFRs) and the total fertility rate (TFR) by union type. We do not interpret this TFR as an approximation of completed fertility, which it is not when computed for a time-varying characteristic such as conjugal situation, but as a measure of the overall intensity of fertility within each union type. We estimate ASFRs and TFR using an approach that combines the own-children method and Poisson regression, which allows us to compute standard errors and thus test whether observed differences between marriage and consensual union are statistically significant.

Castro-Martín et al. (2011) report that apart from the level of education, in which we are mainly interested, other markers of social position-labor force status, rural/urban residence, and home ownership - have a net effect on childbearing outside of marriage. Labor force status could be of special importance given the recent increase in the labor participation rate of women throughout Latin America (Abramo and Valenzuela 2005). Given our interest for the recent uptake of cohabitation among the middle and upper class, we estimate total fertility rates by union type according to educational level, but also according to these three variables.

\section{Measuring fertility within marriage and within consensual union}

According to Heuveline and Timberlake's (2004) typology, cohabitation is an alternative to marriage when individuals choose to cohabit instead of marrying with the intention to form a family as a married couple would. Bearing and rearing children within cohabitation signals that this union type is regarded as an appropriate family setting. Comparing the fertility patterns of women within marriage and consensual union, hence, is relevant to ascertain whether cohabitation has become or is on the way of becoming an accepted alternative to marriage in a given society. However, comparing the fertility within marriage and consensual union involves some technical challenges. Fertility is

commonly estimated using vital statistics, and vital statistics generally report whether children are born to married parents or an unmarried mother, but do not typically report whether the unmarried mother is cohabiting with the child's father. Vital statistics are still largely computed following the traditional distinction between marital and non-marital fertility, and thus have not usually 
incorporated the social phenomenon of cohabitation into the birth statistics. For this reason, it is hard to find fertility estimates by union type based on vital statistics (Klüsener, Perelli-Harris, and Sánchez Gassen 2013). Attempts at estimating fertility within marriage and within consensual union performed since the 1990s show a variety of solutions, but most of them rely on the use of survey data with retrospective histories (e.g. Do Valle Silva, Henriques, and De Souza 1990; Verdugo Lazo 1994; Brown and Dittgen 2000; Raley 2001; Hoem and Mureşan 2011; Van Hook and Altman. 2013). Unfortunately, as we pointed already, the survey data required to make use of these solutions are not available for all Latin American countries.

Dumas and Bélanger (1998) compared levels of fertility within marriage and cohabitation in Canada using data from a retrospective biographical survey, but with an approach that can be used with census data. They estimated five-year age group birth rates for the two union forms, for two tenyear periods, 1975-1984 and 1985-1994, and for two regions, Quebec and the rest of Canada. They computed TFRs for each region and period, based on women's conjugal status at the time of birth. They concluded that the fertility of cohabiting women was lower than that of married women in both regions and in both periods, but that those differences were smaller in Quebec than in the rest of Canada. In this analysis, we adapt their approach to census data. Furthermore, combining the ownchildren method and Poisson regression enables us to estimate standard errors and confidence intervals. See the Technical Appendix for an overview of the own-children method; we explain our use of Poisson regression below.

\section{Conditional age-specific fertility rates and TFR}

Age-specific fertility rates and the total fertility rate are well-established measures of fertility whose meaning and properties are also well known. They are usually defined and computed for all women in reproductive age, commonly women aged between 15 and 49. They are sometimes used in the study of differential fertility and computed for subgroups of women defined by some relevant characteristic such as ethnic group or place of residence. Although we should be cautious with the interpretation, technically, nothing prevents computing age-specific rates within groups defined by a time-varying characteristic such as conjugal situation: this is exactly what the traditional marital fertility rate is. Because these rates are computed within categories of a given variable, they are conditional in the statistical sense and could be referred to as "conditional ASFRs" and the “conditional TFR" respectively. Therefore, in our case, these conditional age-specific fertility rates 
are the rates of giving birth at a given age while being married, living in a consensual union, or not living in a union. The conditional TFR is the sum of such rates and provides an estimate of the number of children born to a woman continuously married, continuously living in a consensual union or continuously not living in a union between the ages 15 and 49 in the year for which the rates are computed. The usual fictitious cohort is broken down into three components that are also fictitious cohorts. The operation can also be interpreted as a decomposition exercise: the usual age-specific rates are decomposed in three sets of rates conditional on conjugal situation. The usual TFR can be interpreted as a weighted sum of the age-specific fertility rates of the three conjugal situations, the weights being the proportions of women living in each of the three conjugal situations (Laplante and Fostik 2015).

Given that, as a rule, women do not spend all of their reproductive years in a conjugal union, and that most children are born to women who live in a union, the TFR of women in marriage and in consensual union are much higher than the TFR for all women. The usual TFR is a measure of period fertility for all women in a given society. The TFR based on some fixed characteristic, such as ethnic group, is a measure of period fertility in the groups defined by these characteristics. The TFR based on a time-varying characteristic, such as conjugal situation, cannot be interpreted as an approximation of completed fertility, as they rely on the unrealistic assumption of being continuously married or cohabiting from age 15 to 49 . However, they are measures of the intensity of fertility within these groups and are a sound and convenient way to compare fertility across such groups.

\section{Poisson regression}

The Poisson distribution is a discrete probability distribution for the counts of events that occur randomly in a given interval of time (Evans, Hastings, and Peacock 2000). Poisson regression is a common tool in epidemiology and demography for estimating rates and the effects of independent variables on rates (Rodriguez and Cleland 1988, Schoumaker 2004). Poisson regression has several advantages for studying fertility. Using it with a piecewise equation allows estimating age-specific rates, and the sum of these rates provides the TFR.

In our calculations, we include the births that occurred in the twelve-month period that preceded the census, i.e. the children less than 1 year old that coresided with their mothers at the time of census. Piecewise equations do not include a coefficient for the intercept; the degree of freedom 
usually associated with the intercept is used to estimate the exact value - i.e. the ASFRs estimatesassociated with each age.

Poisson regression allows using independent variables as any other regression model, but results from preliminary analyses showed that in this particular case, doing so was not the best strategy (see details in the Results section below). We estimate the conditional ASFRs and the TFR separately for each level of education within marriage and within cohabitation. The estimated TFRs are equal to those that would be computed using a simple arithmetical approach, but estimating them with Poisson regression allows us to estimate standard errors and to test the statistical significance of observed differences. See the Technical Appendix for more details.

\section{Results}

We present our results in graphic form for each census and country. Figure 1 depicts age-specific fertility rates for all women by conjugal situation, and Figure 2 represents point estimates and 95\% confidence intervals of the TFR for women in marriage and in consensual union. Detailed estimates, statistical tests, and related statistics are reported in the Annex Table.

\section{Conditional age-specific fertility rates}

Figure 1 depicts age-specific fertility rates for women aged 15 to 49 in marriage, consensual union and not in union. The distribution of these rates for marriage and for consensual union bears little resemblance with the distribution of age-specific rates computed for all women, which commonly peaks around 25. The difference stems from the fact that most women neither are married nor in a consensual union before their $20 \mathrm{~s}$, but those who live with a partner at young ages are likely to have a child soon after they start their conjugal relationship. The ASFRs for marriage and consensual union reflect this pattern. As we stressed earlier, they are not an approximation of completed fertility, but measures of the intensity of fertility within each conjugal situation.

The main result that stems from the graphs of the conditional ASFRs is that generally there is great resemblance in the fertility levels of married women and women living in a consensual union across all ages. The largest differences, when there are any at all, are found among the youngest women - aged 15 to 20-,but these differences are not regular across countries or over time, and could be partly due to random noise if the number of partnered women below age 20 is small. Beyond age 20, there are only minor differences in the direction of slightly higher fertility within 
consensual union than marriage. The overall picture is, therefore, one of analogous reproductive patterns of all women in union, regardless of union type. It is worth mentioning that the similarity of fertility patterns between women in marital and non-marital unions cannot be considered a recent phenomenon, since it was already manifest three or four decades ago, even in countries such as Argentina or Chile, where the overall prevalence of cohabitation was low.

\section{Conditional Total Fertility Rates}

The main result that can be drawn from the TFR estimates by conjugal situation (Figure 2 and Table 4) is that, with very few exceptions, the TFR of cohabiting women is higher than the TFR of married women and, in many cases, the difference is statistically significant. In the few cases where the TFR is lower for cohabiting women than for married women (e.g. Ecuador 1982, Mexico 2000, Uruguay 2006), the differences are small and statistically insignificant.

In most countries, the TFR of married women has declined more rapidly than the TFR of women living in consensual union over the last decades, although there are some exceptions such as Argentina and Uruguay. Consequently, the initial fertility gap between married and cohabiting women has broadened over time, slightly in most countries, but considerably in others such as Brazil.

\section{Conditional TFR for socioeconomic groups}

Preliminary analyses showed that the effect of education on fertility is not proportional: highly educated women have their children later. This did not come as a surprise, but had some practical consequences. The conditional age-specific rates and the effects of the other independent variables cannot be properly estimated without allowing for independent series of conditional ASFRs for each level of education within each conjugal situation. This can be done in a variety of ways. Two things became clear after several different attempts. First, the most substantively interesting results are related to the education level. Second, the relatively small number of highly educated women in many samples does not permit using a method that simultaneously retains the property of estimating coefficients that can be interpreted as conditional ASFRs, allows estimating different series of such coefficients for each educational level within marriage and within consensual union, and allows estimating the effects of the other socioeconomic characteristic we were interested in. We had to make a choice. We chose an approach that allows estimating coefficients that can be interpreted as conditional ASFRs and focusing on the differences across education levels. We estimated the conditional ASFRs and computed the TFR separately for each category of the socioeconomic 
characteristics we consider-education, labor force status, rural/urban residence, and home ownership —within marriage and within cohabitation. As explained above, the estimated TFRs are equal to those that would be computed using a simple arithmetical approach, but using Poisson regression allows estimating standard errors, computing confidence intervals, and testing equality. Results for education are reported in Figure 3. Detailed estimates, statistical tests, and related statistics for all socioeconomic characteristics are available in Table A1.

Some results are in line with what would be expected: low education, economic inactivity, and rural residence are associated with higher fertility. Home ownership, however, does not show a consistent association with fertility across countries and over time; as pointed out by one referee, this could be a consequence of landowning being dissociated from home-owning in slum areas. When we compare fertility rates within-marriage and within-consensual union, the pattern of association between socioeconomic characteristics and fertility does not diverge by type of union, except in the case of education. In all countries, women with university education have the lowest fertility, regardless of type of union. However, the fertility gap between high-educated women and loweducated women is larger among women in consensual union than among their married counterparts. This is so because while the fertility of women with less than primary education tends to be considerably higher among women in consensual union than in marriage, the fertility of women with university education tends to be slightly lower among women in consensual union than in marriage.

Looking at the evolution over time of TFR by educational level within consensual union and marriage provides additional insights. Two general features emerge. First, fertility decreases over time both within marriage and within consensual union in tandem with educational expansion. Second, in most countries, the fertility gap between marriage and consensual union among the highly educated diminishes over time. In many countries, over the last decades, having a child while living in a consensual union has become less and less a distinctive feature of the lower class. Apparently, childbearing within a consensual union is becoming an increasingly frequent option among highly educated women as well.

In fact, in the most recent census, fertility intensity is very similar within non-marital and marital unions for highly educated women. Specifically, fertility within consensual union among women with university education is not statistically different from fertility within marriage in seven out of 12 countries-Brazil, Chile, Colombia, Cuba, Ecuador, Mexico, and Peru—. Even in those countries where fertility is lower within consensual union than marriage-Argentina, Bolivia, Costa Rica and 
Venezuela - , the magnitude of the gap is small. In sum, although consensual unions among the middle and upper classes are a relatively recent phenomenon and still less frequent than in the lower strata, our findings suggest that, in most Latin American countries, the role of cohabitation within the family system is currently equivalent across social strata. Although during the 1980s cohabitation was rare among highly educated women and childbearing within cohabitation even rarer, nowadays highly educated women are entering consensual unions not merely as a childless stage on the way to marriage, but they are having children with their cohabiting partners as if they were married, in the same fashion as their less educated counterparts.

\section{Discussion and conclusion}

Two main findings can be highlighted from the fertility measures computed by conjugal situation. The first is that, with few exceptions, the TFR of consensual union is not only close to, but also slightly higher than the TFR of marriage. The second is that the distributions of ASFRs for marriage and consensual union are very similar across the age range, except before age 20 . The general conclusion we may draw from those findings is that in Latin America, at least for the last four decades, women's fertility patterns depend on their age and on their living in a conjugal union, but not on the legal nature of this union. For the childbearing behavior of women residing with a partner, it does not seem to matter whether they are legally married or not.

Prior studies had already documented that childbearing within consensual unions was widespread in some Latin American countries (Castro-Martín 2002). In this study, we have confirmed this pattern for 13 countries - which represent about $87 \%$ of the total population in the region-over the last four decades. Certainly, this pattern is not unique to Latin America-the probability of having a child is practically the same for cohabiting and married couples in several European countries (Toulemon and Testa 2005; Hoem and Mureşan, 2013)_, but we have documented that it is less of a novelty in the Latin America region. The decoupling of marriage and childbearing has long taken place without a dissociation of partnership and parenthood.

However, the important contribution of this study has been to show that the similarities in reproductive behavior between marital and non-marital unions are not confined to the socially disadvantaged groups, but apply as well to the better off. The negative educational gradient of childbearing within consensual union continues to be the predominant pattern in Latin America, as it is in the United States and in some European countries-mostly in Central and Eastern Europe- 
(Perelli-Harris et al., 2010; Goldstein and Kenney 2012). However, this gradient has become less steep over time in Latin America, partly due to the increasing convergence of marital and non-marital unions regarding childbearing behavior among the highly educated. This was not the usual pattern in the past. Around 1980, the proportion of births to women with tertiary education that took place within a consensual union was below 5\% in all countries except Panama. Nowadays, not only are university-educated women much more likely to enter a consensual union than three or four decades ago, but their childbearing patterns do not differ much from their married counterparts.

As stated in the introduction, there is no broad consensus on whether the recent demographic changes in Latin America should be attributed to modernity and the advance of the Second Demographic Transition in the region, or to the increasing uncertainty that both lower and middle classes are now confronted with. On one hand, recent changes in family dynamics have occurred under far better economic conditions than in the 1980s. On the other hand, the remarkable expansion of education - gross enrolment rates in third-level education rose from 23 to 42 percent between 2000 and 2011 (ECLAC 2013) — entails that some of the privileges conferred by tertiary education in the labor market four decades ago might have dwindled. There are some demographic changes that point in the direction of the STD, such as the increasing number of countries approaching below replacement fertility (Cavenaghi and Alves 2009), the recent boom of cohabitation involving all social strata (Esteve, Lesthaeghe, and López-Gay 2012), the surpassing of children born inside marriage by children born outside marriage since the turn of the century (Castro-Martín et al. 2011), and the emergence of a postponement pattern of first births - though still timid — among the higher educated (Rosero-Bixby, Castro-Martín and Martín-García 2009). Some of the ideational features of the STD, such as increasing secularization and tolerance to various types of non-conformist behaviors like divorce, homosexuality or euthanasia, have also been observed in most Latin American societies (Esteve, Lesthaeghe, and López-Gay 2012). Rising education among younger cohorts is probably a fundamental factor driving ideational change and creating a context of growing tolerance for different life styles and family behaviors. However, a recent study by Covre-Sussai (2013) found that, although national contexts of higher tolerance were related to the occurrence of cohabitation in the higher educated groups, at the individual level, women in the upper strata were not necessarily more tolerant in their values than lower educated ones.

As it is the case in more developed countries (Heuveline and Timberlake 2004, Sassler and Miller 2011; Hiekel and Castro-Martín 2014), the meaning attached to cohabitation—as well as the 
perceived advantages of marriage - is likely to differ across societies in Latin America and across women with different social background (Covre-Sussai et al. 2014). Our a priori expectations, in line with traditional patterns and what is still the most common opinion, were that consensual union in the lower social strata would be related to economic constraints and would serve as a surrogate for marriage, and that consensual union in the upper social strata would be related to women's empowerment and would serve as an adaptative strategy to postpone motherhood until marriage. However, the findings from this study did not fully confirm these expectations. Whereas childbearing within consensual union among highly educated women was uncommon in the 1980s, nowadays fertility levels within cohabitation and marriage are alike among the higher educated. Therefore, the emergent pattern of cohabitation among the upper strata cannot be merely considered as a transitory prelude to marriage, but a much longer life cycle stage where childbearing takes place, as it has traditionally happened in the lower strata.

In sum, in addition to the coexistence of marriage and consensual union in the Latin American region, we should be aware of the coexistence of several types of consensual unions: some are linked to historical cultural legacies, some are poverty-driven or a strategy to cope with unplanned pregnancy, and some favor interpersonal commitment above institutional regulation. Consensual unions in the higher and lower strata probably have different motives and rationales, and acknowledging the existing diversity of consensual unions and the corresponding consequences in the event of dissolution for the well-being of children is still an unsettled challenge for public policies. The adoption of cohabitation by the highly educated has probably been facilitated by the wide social recognition conferred to consensual unions in the lower social strata, as this behavior did not run counter to existing moral and legal codes. Likewise, it is possible that the diffusion of childbearing within consensual union in the upper social strata may have been facilitated by changes in other aspects of family life. Among those, two maybe of special importance: the increase in the labor force participation of women and the advances in the economic protection of children in the event of union disruption that have been implemented in most Latin American countries. Some other institutional factors may be at play. Most Latin American countries typically maintain a somewhat decent system of public health: as in most European countries, access to basic health care is universal and unrelated with family status. Such a factor could be among the reasons why family formation within unmarried cohabitation is increasing faster in Latin America and, for instance, in the UK, than 
in the USA. Future research on the diffusion of childbearing within consensual union in Latin America could examine such hypotheses.

\section{Technical Appendix}

\section{The own-children method of fertility estimation}

The own-children method is an indirect technique for the estimation of fertility by age using census data (Cho, Rutherford, and Choe 1986). Its original form uses the distribution of the number of children less than five years old in the household conditional on the age of mothers aged between 15 and 49, grouped into five-year classes. It was developed for the USA census, mainly to relate fertility measures with characteristics available in the census, but not in vital statistics. Using the number of children less than five years old allowed comparability with the "fertility ratio", a measure based on this number and commonly used at the time the original authors introduced the method. The most obvious difficulties and limitations of this method are establishing the relationship between mother and child from census records, census undercoverage of children and women, infant mortality, and children who do not live with their mother (Grabill and Cho 1965).

In our analyses, we use the information provided in IPUMS files on the age of the youngest child of women aged between 15 and 49 (cf. Sobek and Kennedy 2009). We use only the births that occurred in the year preceding the census, i.e. children less than 1 year of age at census date. This would not be an optimal strategy if our main objective were to estimate age-specific rates with small variance, but it is better suited to our goal of comparing marital and non-marital unions than using the

original five-year period. Some women may have got married between the birth of the child and the time of census, and some women who were not living with a partner may have started living in a consensual union after the birth of the child. In addition, some women married or living in a consensual union at the time the child was born may be living alone at the time of census. These potential changes in union status are less likely over a one-year period than over a five-year period. Nevertheless, if the birth of a child tends to trigger the transformation of a consensual union into marriage in the first year of the child's life, the within-marriage ASFRs and TFR will be overestimated whereas the within-consensual union ASFRs and TFR will be underestimated. 


\section{Poisson regression}

Formally, for any given individual, the Poisson regression model we use may be written as

$$
\hat{r}_{i j}=\sum_{i=1}^{3} \sum_{j=15}^{49} s_{i} t_{j} e^{\alpha_{i j}}
$$

with

$$
f\left(y_{i j}\right)=\frac{e^{-r_{i j}} r_{i j}^{y_{i j}}}{y_{i j} !},
$$

where $\hat{r}_{i j}$ is the predicted conditional age-specific fertility rate for age $t_{j}$ within conjugal situation $s_{i}, s_{i}$ and $t_{j}$ are binary indicator variables for conjugal situation $i$ and age $j$ respectively, $\alpha_{i j}$ is the element of the vector of coefficients for conjugal situation $i$ and age $j, y_{i j}$ is the total number of births to women in conjugal situation $i$ and of age $j, f\left(y_{i j}\right)$ is the density function and $y_{i j} !$ stands for the factorial of $y_{i j}$, i.e. the product of all integers from $y_{i j}$ through 1 .

Given that by design, the coefficients are not correlated, the variance of the sum of the conditional age-specific rates is the sum of their variances. Formally,

$$
\operatorname{var}\left(R_{i}\right)=\sum_{j=15}^{49} \operatorname{var}\left(r_{i j}\right),
$$

where $R_{i}$ is the conditional TFR for conjugal situation $i$.

\section{References}

Abramo, Laís and María Elena Valenzuela. 2005. "Women’s labour force participation rates in Latin America," International Labour Review 144(4): 369-399.

Arriagada, Irma. 2002. "Changes and inequality in Latin American families," Cepal Review 77: 135153.

2007. “Familias latinoamericanas: Cambiantes, diversas, desiguales," Papeles de Población 53: 9-22.

Billari, Francesco and Aart Liefbroer. 2004. "Is the Second Demographic Transition a useful concept for demography? Introduction to a debate," Vienna Yearbook of Population Research 2004: 1-3. http://hw.oeaw.ac.at/0xc1aa500d_0x0006201c. 
Binstock, Georgina. 2010. "Tendencias sobre la convivencia, matrimonio y maternidad en áreas urbanas de Argentina," Revista Latinoamericana de Población 3(6): 129-146.

Brown, Elizabeth and Alfred Dittgen. 2000. "Fertility of married and unmarried couples in Europe," paper presented at the FFS flagship conference Partnership and fertility-A revolution?, Brussels, 29-31 May 2000.

Cabella, Wanda. 2009. "Dos décadas de transformaciones de la nupcialidad uruguaya," Estudios Demográficos y Urbanos 24(2): 389-427.

Cabella, Wanda, Andrés Peri, and Constanza Street. 2005. “¿Dos orillas y una transición? La segunda transición demográfica en Buenos Aires y Montevideo en perspectiva biográfica," in Susanna Torrado (ed.), Trayectorias Nupciales, familias ocultas (Buenos Aires, entresiglos). Buenos Aires: Miño y Dávila, pp. 207-231.

Cavenaghi, Suzana, and José Eustáquio Alves. 2009. "Fertility and Contraception in Latin América: Historical Trends, Recent Patterns." In Demographic Transformations and Inequalities in Latin America: Historical Trends and Recent Patterns, edited by S. Cavenaghi, Chapter 6, 161-193. Serie Investigaciones 8. Rio de Janeiro: Latin American Population Association.

Castro-Martín, Teresa. 1995. "Women's education and fertility: Results from 26 Demographic and Health Surveys," Studies in Family Planning 26(4): 187-202.

— 2001. "Matrimonios sin papeles en Centroamérica: persistencia de un sistema dual de nupcialidad," in Luis Rosero-Bixby (ed.), Población del Istmo 2000: Familia, migración, violencia y medio ambiente. San José, Costa Rica, Centro Centroamericano de Población, pp. 41-65.

http://ccp.ucr.ac.cr/libros/poblaist/pdf/poblacion_istmo.pdf

- 2002. "Consensual unions in Latin America: persistence of a dual nuptiality system," Journal of Comparative Family Studies 33(1): 35-55.

Castro-Martín, Teresa, Clara Cortina, Teresa Martín-García and Ignacio Pardo. 2011. "Maternidad sin matrimonio en América Latina: un análisis comparativo a partir de datos censales," Notas de Población 93: 37-76. 
Castro-Martín, Teresa, Teresa Martín-García and Dolores Puga González. 2008. “Tipo de unión y violencia de género: una comparación de matrimonios y uniones consensuales," in Laura Rodríguez Wong (org.), Población y salud sexual y reproductiva en América Latina. Río de Janeiro, Asociación Latinoamericana de Población.

http://www.alapop.org/docs/publicaciones/investigaciones/SSR_parteIV-1.pdf

CEPAL. 2002. Vulnerabilidad sociodemográfica: viejos y nuevos riesgos para comunidades, hogares y personas. Brasilia, 6-10 Mayo 2002. LC/R.2086. http://www.eclac.cl/publicaciones/xml/4/10264/LCR2086_ind.pdf

Cho, Lee-Jay, Robert D. Rutherford, and Minja Kim Choe. 1986. The own-children method of fertility estimation. Honolulu HI: University of Hawaii Press.

Covre-Sussai, Maira. 2013. Cohabitation in Latin America and developed countries: A cross-national perspective. International Journal of Humanities and Social Science 3(16): 29-43.

Covre-Sussai, Maira, Jan Van Bavel, Koenraad Matthijs and Gray Swicegood. 2014. Disentangling the Different Types of Cohabitation in Latin America: Gender Symmetry and Contextual Influences.

Available at SSRN: http://ssrn.com/abstract=2376739 or http://dx.doi.org/10.2139/ssrn.2376739.

De Vos, Susan. 2000. "Nuptiality in Latin America," in Sandra Lee Browning and R. Robin Miller (eds.), Till Death Do Us Part: A Multicultural Anthology on Marriage. Stamford, CT: JAI Press, pp. 219-243.

Do Valle Silva, Nelson, Maria Helena F. T. Henriques and Amaury de Souza. 1990. An analysis of reproductive behavior in Brazil, Instituto de Estudos Econômicos, Sociais e Politicos de São Paulo and Population Council (Demographic and Health Surveys Further Analysis Series $n^{\circ}$ 6) Dumas, Jean and Alain Bélanger. 1998. Report on the Demographic Situation in Canada 1996. Ottawa, Demography Division, Statistics Canada.

Economic Commission for Latin America and the Caribbean (ECLAC). 2013. Statistical Yearbook for Latin America and the Caribbean 2013. Santiago de Chile: United Nations.

Esteve, Albert, Ron Lesthaeghe, and Antonio López-Gay. 2012. "The Latin American cohabitation boom, 1970-2007," Population and Development Review 38(1): 55-81

Evans, Merran, Nicholas Hastings, and Brian Peacok. 2000. Statistical distributions, $3^{\text {rd }}$ edition. New York, NY: John Wiley and Sons. 
García, Brígida and Olga Rojas. 2004. "Las uniones conyugales en América Latina: Transformaciones en un marco de desigualdad social y de género," Notas de Población 78: 6596.

Goldstein, Joshua R. and Catherine T. Kenney. 2012. "Too poor to marry? A cross-national comparison of the SES gradient in non-marriage", Paper presented at the European Population Conference, Stockholm, 13-16 June 2012.

Grabill, Wilson H. and Lee-Jay. Cho. 1965. "Methodology for the measurement of current fertility from population data on young children," Demography 2: 50-73.

Greene, Margaret E. 1991. The importance of being married: Marriage choice and its consequences in Brazil. Doctoral Dissertation, University of Pennsylvania.

Harbitz, Mia Elisabeth, Juan Carlos Benítez Molina, and Iván Arcos Axt. 2010. Inventario de los registros civiles e identificación de América Latina y el Caribe. Washington DC: Banco Interamericano de Desarrollo.

Heuveline, Patrick and Jeffrey M. Timberlake. 2004. "The role of cohabitation in family formation: The United States in comparative perspective," Journal of Marriage and Family 66(5): 12141230.

Hiekel, Nicole and Teresa Castro-Martín. 2014. "Grasping the diversity of cohabitation: Fertility intentions among cohabiters across Europe," Journal of Marriage and Family 76(3): 489-505.

Hoem, Jan M., Cornelia Mureşan and Mihaela Hărăguş. 2013. Recent features of cohabitational and marital fertility in Romania. Max Planck Institute for Demographic Research, Working Paper WP 2013-007.

Hoem, Jan M. and Cornelia Mureşan. 2011. "The Total Marital Fertility Rate and its extensions," European Journal of Population 27:295-312

Kiernan, Kathleen. 2001. "The rise of cohabitation and childbearing outside marriage in Western Europe," International Journal of Law, Policy and the Family 15(1): 1-21.

Kiernan, Kathleen, Sara McLanahan, John Holmes and Melanie Wright. 2011. Fragile Families in the US and UK. Center for Research on Child Well-Being, Princeton University, Working Paper WP 11-04-FF.

Klüsener, Sebastian, Brienna Perelli-Harris, and Nora Sánchez Gassen. 2013. "Spatial aspects of the rise of non-marital fertility across Europe since 1960: The role of states and regions in shaping patterns of change," European Journal of Population 29:137-165. 
Laplante, Benoît and Ana Laura Fostik. 2015. "Two period measures for comparing the fertility of marriage and cohabitation," Demographic Research 32(14): 421-442.

Laplante, Benoît and María Constanza Street. 2009. "Los tipos de unión consensual en Argentina entre 1995 y 2003: una aproximación biográfica," Estudios Demográficos y Urbanos 24(2): 351-87.

Lesthaeghe, Ron. 1995. "The Second Demographic Transition in Western countries: An interpretation,".in Karen Oppenheim Mason and An-Magritt Jensen (eds.), Gender and Family Change in Industrialized Countries. Oxford, UK: Clarendon Press, pp. 17-62.

- 2010. "The unfolding story of the Second Demographic Transition," Population and Development Review 36(2): 211-252.

Minnesota Population Center. 2013. Integrated public use microdata series, international: Version 6.2 [Machine-readable database]. Minneapolis, MN: University of Minnesota.

Parrado, Emilio and Marta Tienda. 1997. “Women's roles and family formation in Venezuela: New forms of consensual unions?," Social Biology 44(1-2): 1-24.

Perelli-Harris, B., Sigle-Rushton, W., Kreyenfeld, M., Lappegård, T., Keizer, R., Berghammer, C. Perelli-Harris, Brienna, Wendy Sigle-Rushton, Michaela Kreyenfeld, Trude Lappegård, Renske Keizer, and Caroline Berghammer. 2010. "The educational gradient of childbearing within cohabitation in Europe", Population and Development Review 36(4): 775-801.

Quilodrán, Julieta. 1999. “L'union libre en Amérique Latine: aspects récents d'un phénomène séculaire," Cahiers Québécois de Démographie 28(1-2): 53-80.

_. 2011. "Un modelo de nupcialidad post-transicional en América Latina?” In G. Binstock and J. Melo (Eds.), Nupcialidad y familia en la América Latina actual (pp. 11-33). Rio de Janeiro: ALAP.

Quilodrán, Julieta and Teresa Castro-Martín. 2009. "Nuevas dinámicas familiares,”. Estudios Demográficos y Urbanos 24(2): 283-912.

Raley, R. Kelly. 2001. "Increasing fertility in cohabiting unions: Evidence for the Second Demographic Transition in the United States?," Demography 38(1): 59-66.

Rodriguez, German and John Cleland. 1988. "Modelling marital fertility by age and duration: An empirical appraisal of the Page model," Population Studies 42(2): 241-257. 
Rodríguez, Jorge. 2005. "Cohabitación y matrimonio: Disparidades en el origen y en el desempeño y sus implicaciones en materia de protección social," in Irma Arriagada (ed.), Políticas hacia las Familias, Protección e Inclusión Social. Santiago: CEPAL (Serie Seminarios y Conferencias).

Rodríguez Vignoli, Jorge. 2004. "Cohabitación en América Latina: ¿Modernidad, exclusión o diversidad?," Papeles de Población 40: 97-145.

— 2011. "La situación conyugal en los censos latinoamericanos de la década de 2000: relevancia y perspectivas," in Magda Ruiz Salguero and Jorge Rodríguez Vignoli (eds.), Familia y nupcialidad en los censos latinoamericanos recientes: una realidad que desborda los datos. Santiago: CELADE (Serie Población y Desarrollo no 99), pp. 47-70.

http://www.eclac.org/publicaciones/xml/9/42709/lcl3293e-P.pdf

Rosero-Bixby, Luis, Teresa Castro-Martín and Teresa Martín-García. 2009. "Is Latin America starting to retreat from early and universal childbearing?" Demographic Research, Volume 20, Article 9, pp. 169-194.

Sassler, Sharon and Amanda J. Miller. 2011. Class differences in cohabitation processes. Family Relations 60(2): 163-177.

Schoumaker, Bruno. 2004. "Une approche personnes-périodes pour l'analyse des histoires génésiques," Population 59(5): 783-796.

Seltzer, Judith A. 2000. "Families formed outside of marriage," Journal of Marriage and the Family 62(4): $1247-1268$.

Sobek, Matthew and Sheela Kennedy. 2009. The development of family interrelationship variables for international census data. Minnesota Population Center (Working Paper No. 2009-02)

Sobotka, Thomas and Laurent Toulemon. 2008. "Changing family and partnership behaviour: Common trends and persistent diversity across Europe," Demographic Research, vol. 19, art. 6 Socolow, Susan M. 2000. The Women of Colonial Latin America. NY: Cambridge University Press. Toulemon, Laurent and Maria Rota Testa. 2005. Fertility intentions and actual fertility: A complex relationship. Population and Societies no. 415.

Van Hook, Jennifer and Claire E. Altman. 2013. "Using Discrete-Time Event History Fertility Models to Simulate Total Fertility Rates and Other Fertility Measures," Population Research and Policy Review 32:585-610. 
Verdugo Lazo, Aida. 1994. Marital fertility in Brazil: Differential by type of union and its importance in the fertility transition, 1976-1991. Calverton MD: Macro International Inc. (DHS Working Papers $\left.n^{0} 15\right)$. 
TABLE 1 Proportion of women living in consensual union among women aged 15-49 in conjugal union, according to most recent data source

\begin{tabular}{lcc}
\hline & Percentage & Source and date \\
\hline Dominican Republic & 73.9 & DHS 2007 \\
Panama & 64.1 & Census 2010 \\
Honduras & 62.3 & DHS 2011-2012 \\
Nicaragua & 59.8 & RHS 2006/07 \\
Peru & 59.5 & DHS 2012 \\
Colombia & 58.3 & DHS 2010 \\
Uruguay & 52.7 & Census 2011 \\
Cuba & 49.4 & Census 2002 \\
El Salvador & 48.9 & Census 2007 \\
Venezuela & 47.8 & Census 2001 \\
Ecuador & 43.8 & RHS 2004 \\
Brazil & 43.5 & Census 2010 \\
Costa Rica & 39.6 & Census 2011 \\
Paraguay & 39.5 & RHS 2004 \\
Bolivia & 37.0 & DHS 2008 \\
Guatemala & 33.1 & RHS 2002 \\
Mexico & 33.0 & Census 2010 \\
Argentina & 30.6 & Census 2001 \\
Chile & 19.8 & Census 2002 \\
\hline
\end{tabular}

Sources: Census, Demographic and Health Surveys (DHS); Reproductive Health Surveys (RHS). 
TABLE 2 Proportion of births from unmarried mothers according to vital statistics

\begin{tabular}{lcccc}
\hline & Year & Percentage & Year & Percentage \\
\hline Argentina & 1980 & 29.8 & 2000 & 57.6 \\
Chile & 1970 & 18.8 & 2010 & 68.0 \\
Costa Rica & 1970 & 29.4 & 2010 & 67.4 \\
Cuba & - & - & 2011 & 80.7 \\
Ecuador & 1966 & 32.0 & - & - \\
El Salvador & 1970 & 67.8 & 1998 & 72.8 \\
Guatemala & 1970 & 61.9 & - & - \\
Mexico & 1970 & 27.3 & 2010 & 59.4 \\
Panama & 1970 & 70.9 & 2002 & 79.9 \\
Paraguay & 1970 & 42.6 & 2011 & 67.8 \\
Peru & 1972 & 41.3 & 2000 & 58.3 \\
Dominican Republic & - & - & 2011 & 89.8 \\
Uruguay & 1970 & 21.1 & 2001 & 55.2 \\
Venezuela & 1970 & 38.8 & 2010 & 83.5 \\
\hline
\end{tabular}

Sources: United Nations Demographic Yearbook; World Fertility Report; National Institutes of Statistics 
TABLE 3 Evolution of the distribution of births according to the conjugal situation of the mother in selected countries from Latin America, 1970-2000

\begin{tabular}{lcccc}
\hline & 1970 & 1980 & 1990 & 2000 \\
\hline Not in umion & 7.3 & 7.7 & 10.9 & 15.0 \\
Consensual union & 16.8 & 18.0 & 26.8 & 38.9 \\
Marriage & 75.9 & 74.3 & 62.3 & 46.1 \\
\hline
\end{tabular}

Source: Census microdata, IPUMS-International. Countries included: Argentina, Bolivia, Brazil, Chile, Colombia, Costa Rica, Cuba, Ecuador, Mexico, Panama, Peru, Uruguay, and Venezuela. 
TABLE 4 Estimates of the total fertility rate of women living in selected Latin American countries according to their conjugal situation using data from censuses of the four most recent censuses round. Estimates from the own-children method. Women aged 15-49. Census data from IPUMS. Weighted estimation.

\begin{tabular}{|c|c|c|c|c|c|c|c|c|c|c|c|c|}
\hline & \multicolumn{3}{|c|}{ Argentina } & \multicolumn{2}{|c|}{ Bolivia } & \multicolumn{4}{|c|}{ Brazil } & \multicolumn{3}{|c|}{ Chile } \\
\hline & 1980 & 1991 & 2001 & & 01 & 1980 & 1991 & 2000 & 2010 & 1982 & 1992 & 2002 \\
\hline \multicolumn{13}{|l|}{ TFR } \\
\hline All women & 2.90 & 2.71 & 2.30 & \multicolumn{2}{|c|}{2.84} & 3.67 & 2.40 & 2.02 & 1.57 & 2.36 & 2.21 & 1.58 \\
\hline Married & 5.34 & 4.56 & 4.65 & \multicolumn{2}{|c|}{4.33} & 6.27 & 4.38 & 3.52 & 2.64 & 4.69 & 3.79 & 2.93 \\
\hline In consensual union & $5.90^{* * *}$ & $5.73^{* * *}$ & 4.74 & \multicolumn{2}{|c|}{$5.15^{* * *}$} & $6.54^{* * *}$ & $4.93^{* * *}$ & $4.28^{* * *}$ & $3.18^{* * *}$ & 4.72 & $4.22^{* * *}$ & $3.22^{* *}$ \\
\hline Alone & 0.59 & 0.72 & 0.77 & \multicolumn{2}{|c|}{1.01} & 0.64 & 0.68 & 0.78 & 0.64 & 0.80 & 0.87 & 0.79 \\
\hline \multirow[t]{3}{*}{ Unknown situation } & - & - & - & & - & 2.19 & 3.52 & - & - & - & - & - \\
\hline & \multicolumn{3}{|c|}{ Colombia } & \multicolumn{2}{|c|}{ Costa Rica } & Cuba & \multicolumn{4}{|c|}{ Ecuador } & \multicolumn{2}{|c|}{ Mexico } \\
\hline & 1985 & 1993 & 2005 & 1984 & 2000 & 2002 & 1982 & 1990 & 2001 & 2010 & 2000 & 2010 \\
\hline \multicolumn{13}{|l|}{ TFR } \\
\hline All women & 2.27 & 1.88 & 1.90 & 3.02 & 2.23 & 1.51 & 3.72 & 2.74 & 2.11 & 1.98 & 2.30 & 1.96 \\
\hline Married & 3.92 & 3.09 & 3.20 & 4.86 & 3.80 & 2.23 & 5.77 & 4.51 & 3.39 & 3.35 & 4.29 & 3.74 \\
\hline In consensual union & $4.44^{* * *}$ & $3.55^{* * *}$ & $3.72^{* * *}$ & 5.34 & $4.35^{* *}$ & $2.42^{*}$ & 5.71 & $4.72^{*}$ & 3.53 & 3.45 & 4.23 & 3.86 \\
\hline Alone & 0.74 & 0.65 & 0.88 & 1.35 & 1.06 & 0.58 & 1.07 & 0.71 & 0.67 & 0.83 & 0.60 & 0.66 \\
\hline \multirow[t]{3}{*}{ Unknown situation } & 0.63 & 0.42 & 0.67 & - & - & - & 1.18 & 0.75 & 0.80 & - & 1.24 & 0.43 \\
\hline & \multicolumn{4}{|c|}{ Panama } & \multicolumn{2}{|c|}{ Peru } & \multicolumn{3}{|c|}{ Uruguay } & \multicolumn{3}{|c|}{ Venezuela } \\
\hline & 1980 & 1990 & 2000 & 2010 & 1993 & 2007 & 1985 & 1996 & 2006 & 1981 & 1990 & 2001 \\
\hline \multicolumn{13}{|l|}{ TFR } \\
\hline All women & 3.05 & 2.50 & 2.60 & 2.12 & 2.89 & 1.98 & 2.38 & 2.24 & 1.68 & 3.23 & 2.77 & 1.93 \\
\hline Married & 4.44 & 3.99 & 3.88 & 3.10 & 4.72 & 3.24 & 4.73 & 3.90 & 3.79 & 5.07 & 4.58 & 3.27 \\
\hline In consensual union & $5.25^{* * *}$ & $4.53^{*}$ & $4.66^{*}$ & $3.94^{* *}$ & $5.49^{* * *}$ & $3.69^{* * *}$ & 4.98 & $4.70^{* *}$ & 3.56 & $6.17^{* * *}$ & $5.41^{* * *}$ & $3.88^{* * *}$ \\
\hline Alone & 1.27 & 1.02 & 1.15 & 0.92 & 0.79 & 0.64 & 0.56 & 0.76 & 0.64 & 1.30 & 1.21 & 0.78 \\
\hline Unknown situation & - & - & - & - & 0.98 & - & - & - & - & 1.07 & 0.32 & 0.44 \\
\hline
\end{tabular}

${ }^{*}: p<0.05 ;{ }^{* *}: p<0.01 ;{ }^{* * *}: p<0.001$. Each test compares the estimated TFR for consensual union to the corresponding estimate for marriage. 
TABLE A1 Estimates of the total fertility rate of women living in selected Latin American countries according to selected socioeconomic characteristics by conjugal situation using data from censuses of the four most recent censuses round. Estimates from the own-children method and Poisson regression. Women aged 15-49. Census data from IPUMS. Weighted estimation.

\begin{tabular}{|c|c|c|c|c|c|c|c|c|c|c|c|c|}
\hline & \multicolumn{6}{|c|}{ Argentina } & \multicolumn{6}{|c|}{ Chile } \\
\hline & \multicolumn{3}{|c|}{ Marriage } & \multicolumn{3}{|c|}{ Consensual union } & \multicolumn{3}{|c|}{ Marriage } & \multicolumn{3}{|c|}{ Consensual union } \\
\hline & 1980 & 1991 & 2001 & 1980 & 1991 & 2001 & 1982 & 1992 & 2002 & 1982 & 1992 & 2002 \\
\hline Education level & & & & & & & & & & & & \\
\hline $\begin{array}{l}\text { Less than primary } \\
\text { Primary } \\
\text { Secondary } \\
\text { University }\end{array}$ & $\begin{array}{l}5.67 \\
5.20 \\
3.94 \\
4.40\end{array}$ & $\begin{array}{l}4.64 \\
4.53 \\
4.21 \\
3.32\end{array}$ & $\begin{array}{l}5.19 \\
4.45 \\
4.03 \\
3.48\end{array}$ & $\begin{array}{l}6.68^{* * *} \\
5.12 \\
4.13 \\
3.58\end{array}$ & $\begin{array}{l}6.49^{* * *} \\
5.54^{* * *} \\
3.43^{* *} \\
3.85^{* *}\end{array}$ & $\begin{array}{l}5.92^{*} \\
4.73^{*} \\
3.91 \\
2.20^{* * *}\end{array}$ & $\begin{array}{l}4.71 \\
4.57 \\
3.98 \\
3.09\end{array}$ & $\begin{array}{l}3.37 \\
3.70 \\
3.59 \\
3.26\end{array}$ & $\begin{array}{l}2.65 \\
2.84 \\
2.63 \\
2.42\end{array}$ & $\begin{array}{l}5.23 \\
4.53 \\
3.25 \\
1.50^{* * *}\end{array}$ & $\begin{array}{l}4.46^{* * *} \\
4.23^{* * *} \\
3.83 \\
3.03\end{array}$ & $\begin{array}{l}3.17 \\
3.19^{* *} \\
3.07 \\
1.85\end{array}$ \\
\hline Labor force status & & & & & & & & & & & & \\
\hline $\begin{array}{l}\text { Employed } \\
\text { Unemployed } \\
\text { Inactive }\end{array}$ & $\begin{array}{l}3.48 \\
5.57 \\
5.79\end{array}$ & $\begin{array}{l}3.43 \\
3.45 \\
5.16\end{array}$ & $\begin{array}{l}3.22 \\
3.82 \\
5.32\end{array}$ & $\begin{array}{l}2.60 \\
10.37^{* * *} \\
6.73^{\text {*** }}\end{array}$ & $\begin{array}{l}4.01^{* * *} \\
4.35^{* *} \\
6.81^{\text {*** }}\end{array}$ & $\begin{array}{l}3.49 \\
4.13 \\
5.70^{* *}\end{array}$ & $\begin{array}{l}2.97 \\
3.38 \\
4.93\end{array}$ & $\begin{array}{l}2.64 \\
2.61 \\
3.99\end{array}$ & $\begin{array}{l}1.95 \\
1.47 \\
3.33\end{array}$ & $\begin{array}{l}2.25 \\
2.87 \\
5.17\end{array}$ & $\begin{array}{l}1.99^{* *} \\
1.03^{* *} \\
4.57^{* * *}\end{array}$ & $\begin{array}{l}1.76 \\
1.91 \\
3.79^{* * *}\end{array}$ \\
\hline $\begin{array}{l}\text { Area } \\
\text { Rural } \\
\text { Urban }\end{array}$ & $\begin{array}{l}6.19 \\
5.25\end{array}$ & $\begin{array}{l}5.11 \\
4.53\end{array}$ & $\begin{array}{l}5.00 \\
4.58\end{array}$ & $\begin{array}{l}7.45^{* * *} \\
5.50\end{array}$ & $\begin{array}{l}6.81^{* * *} \\
5.60^{* * *}\end{array}$ & $\begin{array}{l}5.84^{* * *} \\
4.57\end{array}$ & $\begin{array}{l}5.29 \\
4.59\end{array}$ & $\begin{array}{l}4.04 \\
3.74\end{array}$ & $\begin{array}{l}3.00 \\
2.90\end{array}$ & $\begin{array}{l}5.36 \\
4.59\end{array}$ & $\begin{array}{l}5.28^{* * *} \\
4.03^{*}\end{array}$ & $\begin{array}{l}3.42 \\
3.19^{*}\end{array}$ \\
\hline $\begin{array}{l}\text { Home ownership } \\
\text { Owner } \\
\text { Other }\end{array}$ & $\begin{array}{l}5.05 \\
5.96\end{array}$ & $\begin{array}{l}4.27 \\
5.18 \\
\end{array}$ & $\begin{array}{l}4.51 \\
4.95\end{array}$ & $\begin{array}{l}5.43^{*} \\
6.48^{* *}\end{array}$ & $\begin{array}{l}5.60^{* * * *} \\
5.99^{* * * *}\end{array}$ & $\begin{array}{l}4.68 \\
4.97 \\
\end{array}$ & $\begin{array}{l}4.53 \\
4.99 \\
\end{array}$ & $\begin{array}{l}3.65 \\
4.10 \\
\end{array}$ & $\begin{array}{l}2.87 \\
3.09 \\
\end{array}$ & $\begin{array}{l}4.47 \\
5.11 \\
\end{array}$ & $\begin{array}{l}3.99^{*} \\
4.64^{*}\end{array}$ & $\begin{array}{l}3.15^{*} \\
3.37\end{array}$ \\
\hline
\end{tabular}


TABLE A1 Estimates of the total fertility rate of women living in selected Latin American countries according to selected socioeconomic characteristics by conjugal situation using data from censuses of the four most recent censuses round. Estimates from the own-children method and Poisson regression. Women aged 15-49. Census data from IPUMS. Weighted estimation. (Continued).

\begin{tabular}{|c|c|c|c|c|c|c|c|c|c|c|}
\hline & \multicolumn{2}{|c|}{ Bolivia } & \multicolumn{8}{|c|}{ Brazil } \\
\hline & \multirow{2}{*}{$\frac{\text { Marriage }}{2001}$} & \multirow{2}{*}{$\begin{array}{c}\text { Consensual } \\
2001\end{array}$} & \multicolumn{4}{|c|}{ Marriage } & \multicolumn{4}{|c|}{ Consensual union } \\
\hline & & & 1980 & 1991 & 2000 & 2010 & 1980 & 1991 & 2000 & 2010 \\
\hline \multicolumn{11}{|l|}{ Education level } \\
\hline $\begin{array}{l}\text { Less than primary } \\
\text { Primary } \\
\text { Secondary } \\
\text { University }\end{array}$ & $\begin{array}{l}5.22 \\
4.04 \\
3.36 \\
2.74\end{array}$ & $\begin{array}{l}5.77^{*} \\
4.68^{* * *} \\
4.05^{*} \\
2.44^{* * *}\end{array}$ & $\begin{array}{l}6.50 \\
5.33 \\
4.75 \\
3.84\end{array}$ & $\begin{array}{l}4.64 \\
3.92 \\
3.73 \\
2.82\end{array}$ & $\begin{array}{l}3.83 \\
3.23 \\
3.08 \\
2.37\end{array}$ & $\begin{array}{l}2.56 \\
2.54 \\
2.54 \\
2.19\end{array}$ & $\begin{array}{l}6.77^{\text {*** }} \\
5.14 \\
4.01^{\text {*** }} \\
2.93^{\text {*** }}\end{array}$ & $\begin{array}{l}5.19^{* * * *} \\
4.38^{* * *} \\
3.87 \\
3.13\end{array}$ & $\begin{array}{l}4.55^{* * *} \\
3.97^{* * *} \\
3.54^{* * *} \\
2.34\end{array}$ & $\begin{array}{l}3.37^{* * *} \\
3.20^{* * *} \\
2.87^{*} \\
1.94\end{array}$ \\
\hline \multicolumn{11}{|l|}{ Labor force status } \\
\hline $\begin{array}{l}\text { Employed } \\
\text { Unemployed } \\
\text { Inactive }\end{array}$ & $\begin{array}{l}3.67 \\
2.78 \\
4.79\end{array}$ & $\begin{array}{l}4.08 \\
4.37^{* * *} \\
5.93^{* * *}\end{array}$ & $\begin{array}{l}4.47 \\
5.81 \\
6.66\end{array}$ & $\begin{array}{l}3.19 \\
3.68 \\
4.80\end{array}$ & $\begin{array}{l}2.55 \\
2.56 \\
4.32\end{array}$ & $\begin{array}{l}1.86 \\
1.97 \\
3.63\end{array}$ & $\begin{array}{l}4.58 \\
6.24 \\
7.12^{\text {*** }}\end{array}$ & $\begin{array}{l}3.29 \\
4.22^{*} \\
5.55^{* * *}\end{array}$ & $\begin{array}{l}2.85^{\text {*** }} \\
3.46^{\text {*** }} \\
5.30^{\text {*** }}\end{array}$ & $\begin{array}{l}2.06^{* * *} \\
2.58^{* * *} \\
4.26^{* * *}\end{array}$ \\
\hline \multicolumn{11}{|l|}{ Area } \\
\hline $\begin{array}{l}\text { Rural } \\
\text { Urban }\end{array}$ & $\begin{array}{l}5.16 \\
3.88\end{array}$ & $\begin{array}{l}5.89^{* *} \\
4.81^{* * *}\end{array}$ & $\begin{array}{l}7.39 \\
5.78\end{array}$ & $\begin{array}{l}5.28 \\
4.10\end{array}$ & $\begin{array}{l}4.12 \\
3.36\end{array}$ & $\begin{array}{l}2.67 \\
2.62\end{array}$ & $\begin{array}{l}7.76^{* * *} \\
6.12^{* * *}\end{array}$ & $\begin{array}{l}6.02^{* * *} \\
4.66^{* * *}\end{array}$ & $\begin{array}{l}5.04^{* * *} \\
4.12^{* * *}\end{array}$ & $\begin{array}{l}3.48^{* * *} \\
3.11^{* * *}\end{array}$ \\
\hline \multicolumn{11}{|l|}{ Home ownership } \\
\hline $\begin{array}{l}\text { Owner } \\
\text { Other }\end{array}$ & $\begin{array}{l}4.34 \\
4.41 \\
\end{array}$ & $\begin{array}{l}5.02^{* * *} \\
5.41^{* * *}\end{array}$ & $\begin{array}{l}6.30 \\
6.28 \\
\end{array}$ & $\begin{array}{l}4.39 \\
4.41 \\
\end{array}$ & $\begin{array}{l}3.46 \\
3.66 \\
\end{array}$ & $\begin{array}{l}2.57 \\
2.77 \\
\end{array}$ & $\begin{array}{l}6.80^{* * *} \\
6.35\end{array}$ & $\begin{array}{l}4.98^{* * *} \\
4.90^{* * *}\end{array}$ & $\begin{array}{l}4.21^{* * *} \\
4.38^{* * *}\end{array}$ & $\begin{array}{l}3.12^{* * *} \\
3.28^{* * *}\end{array}$ \\
\hline
\end{tabular}

${ }^{*}: p<0.05 ;{ }^{* *}: p<0.01{ }^{* * *}: p<0.001$. Each test compares the estimated TFR for consensual union to the corresponding estimate for marriage. 
TABLE A1 Estimates of the total fertility rate of women living in selected Latin American countries according to selected socioeconomic characteristics by conjugal situation using data from censuses of the four most recent censuses round. Estimates from the own-children method and Poisson regression. Women aged 15-49. Census data from IPUMS. Weighted estimation. (Continued).

\begin{tabular}{|c|c|c|c|c|c|c|c|c|c|c|}
\hline & \multicolumn{6}{|c|}{ Colombia } & \multicolumn{4}{|c|}{ Costa Rica } \\
\hline & \multicolumn{3}{|c|}{ Marriage } & \multicolumn{3}{|c|}{ Consensual union } & \multicolumn{2}{|c|}{ Marriage } & \multicolumn{2}{|c|}{ Consensual union } \\
\hline & 1985 & 1993 & 2005 & 1985 & 1993 & 2005 & 1984 & 2000 & 1984 & 2000 \\
\hline Education level & & & & & & & & & & \\
\hline $\begin{array}{l}\text { Less than primary } \\
\text { Primary } \\
\text { Secondary } \\
\text { University }\end{array}$ & $\begin{array}{l}4.34 \\
3.68 \\
3.16 \\
2.73\end{array}$ & $\begin{array}{l}3.33 \\
2.96 \\
2.95 \\
1.83\end{array}$ & $\begin{array}{l}3.57 \\
2.96 \\
2.91 \\
2.40\end{array}$ & $\begin{array}{l}4.66^{* *} \\
4.16^{* * *} \\
3.97^{* *} \\
3.20\end{array}$ & $\begin{array}{l}3.88^{* * *} \\
3.34^{* * *} \\
3.08 \\
1.79\end{array}$ & $\begin{array}{l}4.18^{* *} \\
3.54^{* * *} \\
3.31 \\
2.64\end{array}$ & $\begin{array}{l}5.07 \\
4.77 \\
3.50 \\
4.59\end{array}$ & $\begin{array}{l}3.73 \\
3.78 \\
3.42 \\
2.70\end{array}$ & $\begin{array}{l}5.75 \\
4.80 \\
3.85 \\
0.33^{\text {** }}\end{array}$ & $\begin{array}{l}4.53^{*} \\
4.45^{\text {** }} \\
2.27^{\text {** }} \\
1.41^{\text {** }}\end{array}$ \\
\hline Labor force status & & & & & & & & & & \\
\hline $\begin{array}{l}\text { Employed } \\
\text { Unemployed } \\
\text { Inactive }\end{array}$ & $\begin{array}{l}3.36 \\
2.49 \\
4.20\end{array}$ & $\begin{array}{l}1.91 \\
2.03 \\
3.52\end{array}$ & $\begin{array}{l}2.14 \\
2.87 \\
3.65\end{array}$ & $\begin{array}{l}3.69^{* *} \\
3.07 \\
4.82^{* * *}\end{array}$ & $\begin{array}{l}2.34^{* * *} \\
1.90^{\text {*** }} \\
4.01^{\text {* }}\end{array}$ & $\begin{array}{l}2.28 \\
2.98 \\
4.20^{\text {*** }}\end{array}$ & $\begin{array}{l}2.97 \\
4.86 \\
5.10\end{array}$ & $\begin{array}{l}2.12 \\
1.92 \\
4.19\end{array}$ & $\begin{array}{l}2.76 \\
3.25^{* *} \\
5.59\end{array}$ & $\begin{array}{l}1.92 \\
1.83 \\
4.90^{* *}\end{array}$ \\
\hline $\begin{array}{l}\text { Area } \\
\text { Rural } \\
\text { Urban }\end{array}$ & $\begin{array}{l}4.54 \\
3.63\end{array}$ & $\begin{array}{l}3.81 \\
2.85\end{array}$ & $\begin{array}{l}3.44 \\
3.11\end{array}$ & $\begin{array}{l}4.65 \\
4.37^{* * *}\end{array}$ & $\begin{array}{l}4.35^{* * *} \\
3.22^{* * *}\end{array}$ & $\begin{array}{l}4.06^{* * *} \\
3.61^{* *}\end{array}$ & $\begin{array}{l}5.23 \\
4.58\end{array}$ & $\begin{array}{l}3.87 \\
3.80\end{array}$ & $\begin{array}{l}5.60 \\
4.76\end{array}$ & $\begin{array}{l}4.63^{* *} \\
4.06\end{array}$ \\
\hline $\begin{array}{l}\text { Home ownership } \\
\text { Owner } \\
\text { Other }\end{array}$ & $\begin{array}{l}3.69 \\
4.31 \\
\end{array}$ & $\begin{array}{l}2.90 \\
3.33 \\
\end{array}$ & $\begin{array}{l}3.06 \\
3.55 \\
\end{array}$ & $\begin{array}{l}4.22^{* * *} \\
4.80^{* * *}\end{array}$ & $\begin{array}{l}3.44^{* * *} \\
3.72^{* * *}\end{array}$ & $\begin{array}{l}3.66^{* * *} \\
3.91\end{array}$ & $\begin{array}{l}4.85 \\
4.90 \\
\end{array}$ & $\begin{array}{l}3.56 \\
4.22 \\
\end{array}$ & $\begin{array}{l}5.45 \\
5.36 \\
\end{array}$ & $\begin{array}{l}4.22^{*} \\
4.47\end{array}$ \\
\hline
\end{tabular}


TABLE A1 Estimates of the total fertility rate of women living in selected Latin American countries according to selected socioeconomic characteristics by conjugal situation using data from censuses of the four most recent censuses round. Estimates from the own-children method and Poisson regression. Women aged 15-49. Census data from IPUMS. Weighted estimation. (Continued).

\begin{tabular}{|c|c|c|c|c|c|c|c|c|c|c|}
\hline & \multicolumn{2}{|c|}{ Cuba } & \multicolumn{8}{|c|}{ Ecuador } \\
\hline & \multirow{2}{*}{$\begin{array}{c}\text { Marriage } \\
2002\end{array}$} & \multirow{2}{*}{$\begin{array}{c}\text { Consensual } \\
2002\end{array}$} & \multicolumn{4}{|c|}{ Marriage } & \multicolumn{4}{|c|}{ Consensual union } \\
\hline & & & 1982 & 1990 & 2001 & 2010 & 1982 & 1990 & 2001 & 2010 \\
\hline \multicolumn{11}{|l|}{ Education level } \\
\hline $\begin{array}{l}\text { Less than primary } \\
\text { Primary } \\
\text { Secondary } \\
\text { University }\end{array}$ & $\begin{array}{l}2.03 \\
2.16 \\
2.00 \\
1.65\end{array}$ & $\begin{array}{l}2.47 \\
2.34 \\
2.12 \\
1.82\end{array}$ & $\begin{array}{l}6.81 \\
4.96 \\
3.93 \\
3.80\end{array}$ & $\begin{array}{l}5.20 \\
4.26 \\
3.76 \\
2.73\end{array}$ & $\begin{array}{l}3.75 \\
3.30 \\
2.89 \\
2.15\end{array}$ & $\begin{array}{l}3.77 \\
3.22 \\
2.90 \\
2.37\end{array}$ & $\begin{array}{l}6.47 \\
4.82 \\
3.21 \\
0.45^{* * *}\end{array}$ & $\begin{array}{l}5.21 \\
4.46 \\
4.61^{*} \\
2.20\end{array}$ & $\begin{array}{l}3.91 \\
3.45 \\
2.65 \\
1.93\end{array}$ & $\begin{array}{l}3.68 \\
3.46^{* *} \\
3.36^{* *} \\
2.27\end{array}$ \\
\hline \multicolumn{11}{|l|}{ Labor force status } \\
\hline $\begin{array}{l}\text { Employed } \\
\text { Unemployed } \\
\text { Inactive }\end{array}$ & $\begin{array}{l}1.52 \\
1.47 \\
2.52\end{array}$ & $\begin{array}{l}1.93 \\
0.93 \\
2.61\end{array}$ & $\begin{array}{l}4.25 \\
2.75 \\
6.07\end{array}$ & $\begin{array}{l}3.42 \\
4.60 \\
4.91\end{array}$ & $\begin{array}{l}2.66 \\
1.20 \\
3.83\end{array}$ & $\begin{array}{l}2.75 \\
2.76 \\
3.83\end{array}$ & $\begin{array}{l}3.63 \\
6.17^{* * *} \\
5.92\end{array}$ & $\begin{array}{l}3.30 \\
3.49 \\
5.01\end{array}$ & $\begin{array}{l}2.42 \\
2.62^{* *} \\
3.91\end{array}$ & $\begin{array}{l}2.62 \\
3.04 \\
3.84\end{array}$ \\
\hline \multicolumn{11}{|l|}{ Area } \\
\hline $\begin{array}{l}\text { Rural } \\
\text { Urban }\end{array}$ & - & - & - & $\begin{array}{l}5.40 \\
4.13\end{array}$ & $\begin{array}{l}3.87 \\
3.21\end{array}$ & $\begin{array}{l}3.72 \\
3.09\end{array}$ & - & $\begin{array}{l}5.23 \\
4.51^{* *}\end{array}$ & $\begin{array}{l}4.14 \\
3.33\end{array}$ & $\begin{array}{l}3.79 \\
3.24\end{array}$ \\
\hline \multicolumn{11}{|l|}{ Home ownership } \\
\hline $\begin{array}{l}\text { Owner } \\
\text { Other }\end{array}$ & - & - & $\begin{array}{l}5.74 \\
5.77 \\
\end{array}$ & $\begin{array}{l}4.39 \\
4.68 \\
\end{array}$ & $\begin{array}{l}3.37 \\
3.43 \\
\end{array}$ & $\begin{array}{l}3.23 \\
3.55 \\
\end{array}$ & $\begin{array}{l}5.67 \\
5.88 \\
\end{array}$ & $\begin{array}{l}4.64^{*} \\
4.88 \\
\end{array}$ & $\begin{array}{l}3.39 \\
3.79^{* *} \\
\end{array}$ & $\begin{array}{l}3.31 \\
3.66 \\
\end{array}$ \\
\hline
\end{tabular}


TABLE A1 Estimates of the total fertility rate of women living in selected Latin American countries according to selected socioeconomic characteristics by conjugal situation using data from censuses of the four most recent censuses round. Estimates from the own-children method and Poisson regression. Women aged 15-49. Census data from IPUMS. Weighted estimation. (Continued).

\begin{tabular}{|c|c|c|c|c|c|c|c|c|c|c|c|c|}
\hline & \multicolumn{4}{|c|}{ Mexico } & \multicolumn{8}{|c|}{ Panama } \\
\hline & \multicolumn{2}{|c|}{ Marriage } & \multicolumn{2}{|c|}{ Consensual } & \multicolumn{4}{|c|}{ Marriage } & \multicolumn{4}{|c|}{ Consensual union } \\
\hline & 2000 & 2010 & 2000 & 2010 & 1980 & 1990 & 2000 & 2010 & 1980 & 1990 & 2000 & 2010 \\
\hline \multicolumn{13}{|l|}{ Education level } \\
\hline Less than primary & 4.62 & 3.70 & 4.44 & $4.29^{* * *}$ & 5.98 & 4.46 & 6.09 & 2.83 & 5.29 & 4.84 & 5.52 & $5.05^{* * *}$ \\
\hline Primary & 4.06 & 3.61 & 4.05 & 3.72 & 3.92 & 4.07 & 3.20 & 3.59 & $5.06^{* * *}$ & 4.48 & $4.59^{* * *}$ & 3.95 \\
\hline Secondary & 3.66 & 3.23 & 3.52 & 3.49 & 3.40 & 3.94 & 3.19 & 2.41 & 3.75 & 3.26 & $4.50^{* * *}$ & 2.63 \\
\hline University & 3.07 & 2.61 & $2.22^{* * *}$ & 2.59 & 2.38 & 2.06 & 2.00 & 1.81 & 2.20 & $3.78^{* *}$ & $3.87^{* * *}$ & 2.01 \\
\hline \multicolumn{13}{|l|}{ Labor force status } \\
\hline Employed & 3.00 & 2.59 & 2.83 & 2.76 & 2.94 & 2.66 & 2.49 & 2.03 & 3.62 & 3.36 & 3.01 & 2.55 \\
\hline Unemployed & 2.35 & 2.40 & 1.66 & 1.93 & 1.96 & 2.13 & 3.62 & 2.28 & 3.08 & $3.63^{*}$ & 3.98 & 2.51 \\
\hline Inactive & 4.67 & 4.09 & 4.70 & $4.28^{* *}$ & 4.92 & 4.18 & 4.49 & 3.61 & $5.77^{* *}$ & $4.80^{*}$ & 5.22 & $4.61^{* *}$ \\
\hline \multicolumn{13}{|l|}{ Area } \\
\hline Rural & 4.81 & - & 4.74 & - & 5.33 & - & 5.44 & 3.39 & 5.65 & - & 5.17 & $4.57^{*}$ \\
\hline Urban & 4.13 & - & 4.07 & - & 3.76 & - & 3.20 & 2.99 & $4.65^{* *}$ & - & $4.27^{* * *}$ & 3.39 \\
\hline \multicolumn{13}{|l|}{ Home ownership } \\
\hline Owner & 4.22 & 3.68 & 4.14 & $3.85^{*}$ & 4.59 & 4.07 & 4.86 & 2.85 & $5.88^{* * *}$ & 4.55 & 4.63 & $4.02^{* * *}$ \\
\hline Other & 4.50 & 3.92 & 4.43 & 3.91 & 4.20 & 3.95 & 3.07 & 3.38 & 4.59 & 4.53 & $4.83^{* * *}$ & 3.63 \\
\hline
\end{tabular}

${ }^{*}: p<0.05 ;^{* *}: p<0.01 ;^{* * *}: p<0.001$. Each test compares the estimated TFR for consensual union to the corresponding estimate for marriage. 
TABLE A1 Estimates of the total fertility rate of women living in selected Latin American countries according to selected socioeconomic characteristics by conjugal situation using data from censuses of the four most recent censuses round. Estimates from the own-children method and Poisson regression. Women aged 15-49. Census data from IPUMS. Weighted estimation. (Continued).

\begin{tabular}{|c|c|c|c|c|c|c|c|c|c|c|}
\hline & \multicolumn{4}{|c|}{ Peru } & \multicolumn{6}{|c|}{ Uruguay } \\
\hline & \multicolumn{2}{|c|}{ Marriage } & \multicolumn{2}{|c|}{ Consensual union } & \multicolumn{3}{|c|}{ Marriage } & \multicolumn{3}{|c|}{ Consensual union } \\
\hline & 1993 & 2007 & 1993 & 2007 & 1985 & 1996 & 2006 & 1985 & 1996 & 2006 \\
\hline \multicolumn{11}{|l|}{ Education level } \\
\hline Less than primary & 5.41 & 3.48 & $5.86^{* * *}$ & $4.24^{* * *}$ & 4.24 & 3.34 & $\grave{\dagger}$ & $5.97^{* *}$ & $5.23^{* * *}$ & 2.84 \\
\hline Primary & 4.32 & 3.12 & $5.23^{* * *}$ & $3.68^{* * *}$ & 4.72 & 3.90 & $\dagger$ & 4.61 & $4.75^{* *}$ & 3.70 \\
\hline Secondary & 4.37 & 2.97 & 4.60 & 3.12 & 5.31 & 3.92 & $\dagger$ & $3.68^{*}$ & $1.84^{* * *}$ & 3.18 \\
\hline University & 3.12 & 2.54 & 2.88 & 2.23 & 3.09 & 2.36 & $\dagger$ & $1.00^{* * *}$ & $0.75^{* * *}$ & 1.31 \\
\hline \multicolumn{11}{|l|}{ Labor force status } \\
\hline Employed & 3.66 & 2.18 & $4.37^{* * *}$ & $2.63^{* * *}$ & 2.97 & 3.48 & 1.96 & 3.55 & $2.57^{*}$ & 2.22 \\
\hline Unemployed & 2.89 & 2.95 & $4.39^{* *}$ & 2.67 & 2.32 & 2.53 & 2.27 & 2.83 & $4.79^{* * *}$ & 2.54 \\
\hline Inactive & 5.12 & 3.71 & $5.83^{* * *}$ & $4.20^{* * *}$ & 5.33 & 4.78 & 4.68 & 5.92 & $6.54^{* * *}$ & 4.96 \\
\hline \multicolumn{11}{|l|}{ Area } \\
\hline Rural & 5.96 & 3.70 & $6.28^{*}$ & $4.44^{* * *}$ & 4.60 & - & - & 5.79 & - & - \\
\hline Urban & 4.31 & 3.05 & $5.11^{* * *}$ & $3.40^{* * *}$ & 4.71 & - & - & 4.92 & - & - \\
\hline \multicolumn{11}{|l|}{ Home ownership } \\
\hline Owner & 4.75 & 3.17 & $5.46^{* * *}$ & $3.70^{* * *}$ & 4.62 & 3.95 & 3.29 & 5.12 & 4.64 & 3.38 \\
\hline Other & 4.71 & 3.46 & $5.62^{* * *}$ & 3.72 & 4.76 & 3.96 & 3.66 & 5.03 & $4.77^{*}$ & 3.86 \\
\hline
\end{tabular}

${ }^{*}: p<0.05 ;{ }^{* *}: p<0.01 ;{ }^{* * *}: p<0.001$. Each test compares the estimated TFR for consensual union to the corresponding estimate for marriage. 'The 2006 "census data" from Uruguay actually come from a survey. The small size of the subsample of married women by education level leads to inconsistent estimates of the TFR. 
TABLE A1 Estimates of the total fertility rate of women living in selected Latin American countries according to selected socioeconomic characteristics by conjugal situation using data from censuses of the four most recent censuses round. Estimates from the own-children method and Poisson regression. Women aged 15-49. Census data from IPUMS. Weighted estimation. (Continued).

\begin{tabular}{|c|c|c|c|c|c|c|}
\hline & \multicolumn{6}{|c|}{ Venezuela } \\
\hline & \multicolumn{3}{|c|}{ Marriage } & \multicolumn{3}{|c|}{ Consensual union } \\
\hline & 1981 & 1990 & 2001 & 1981 & 1990 & 2001 \\
\hline \multicolumn{7}{|l|}{ Education level } \\
\hline Less than primary & 5.71 & 5.10 & 3.54 & $6.72^{* * *}$ & $5.75^{* * *}$ & $4.29^{* * *}$ \\
\hline Primary & 4.76 & 4.46 & 3.14 & $5.42^{* * *}$ & $5.16^{* * *}$ & $3.79^{* * *}$ \\
\hline Secondary & 4.71 & 4.55 & 2.93 & 3.81 & 4.73 & $3.50^{*}$ \\
\hline University & 3.42 & 4.27 & 1.83 & $0.86^{* * *}$ & 3.80 & $0.00^{* * *}$ \\
\hline \multicolumn{7}{|l|}{ Labor force status } \\
\hline Employed & 3.87 & 3.85 & 2.58 & 4.39 & 3.98 & 2.29 \\
\hline Unemployed & 3.53 & 4.16 & 3.21 & 3.74 & 4.20 & 3.45 \\
\hline Inactive & 5.40 & 4.88 & 3.57 & $6.60^{* * *}$ & $5.81^{* * *}$ & $4.30^{* * *}$ \\
\hline \multicolumn{7}{|l|}{ Area } \\
\hline Rural & 6.71 & 5.41 & 3.60 & $7.26^{*}$ & $6.14^{* * *}$ & $4.38^{* * *}$ \\
\hline Urban & 4.87 & 4.47 & 3.25 & $5.87^{* * *}$ & $5.19^{* * *}$ & $3.80^{* * *}$ \\
\hline \multicolumn{7}{|l|}{ Home ownership } \\
\hline Owner & 5.14 & 4.55 & 3.18 & $6.32^{* * *}$ & $5.37^{* * *}$ & $3.74^{* * *}$ \\
\hline Other & 4.90 & 4.73 & 3.50 & $5.90^{* * *}$ & $5.47^{* * *}$ & $4.25^{* * *}$ \\
\hline
\end{tabular}


FIGURE 1 Estimates of the age-specific fertility rates of women aged 15-49 living in selected Latin American countries according to their conjugal situation, 1980-2010.
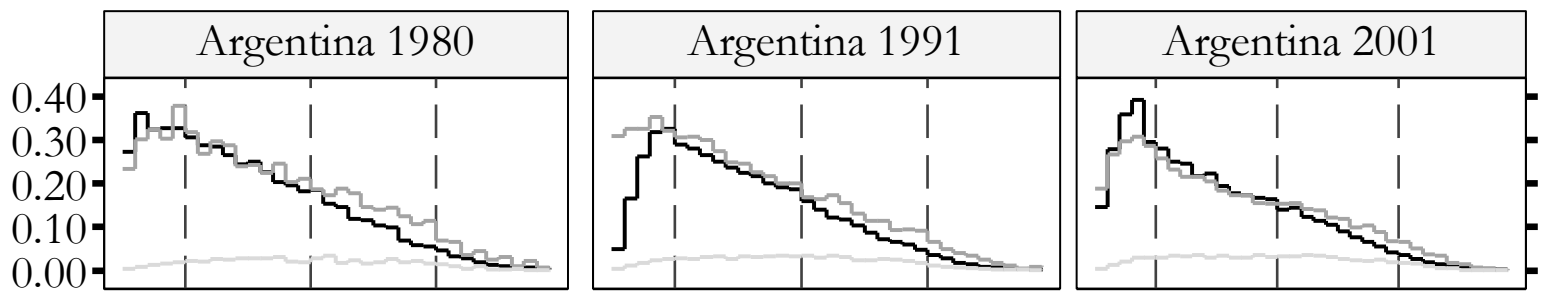

0.40
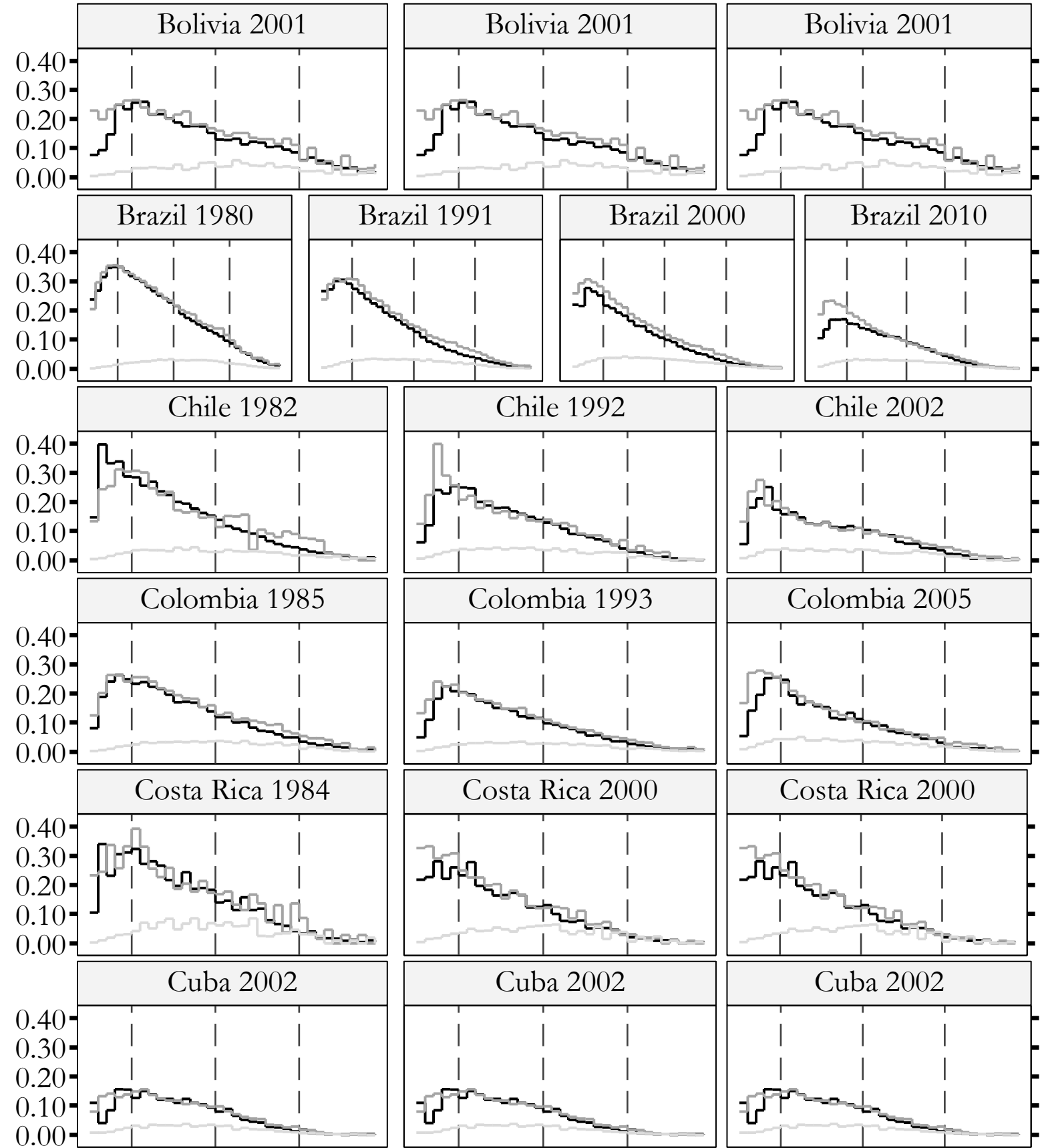

- Marriage

Consensual union

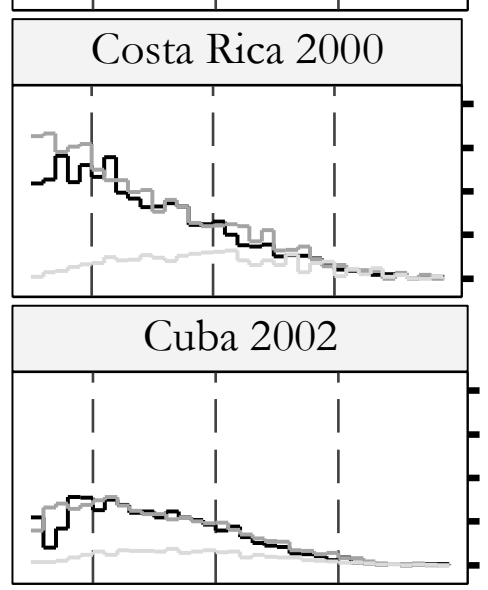

Not in union

Source: Census data from IPUMS. Estimates from the own-children method. Vertical lines at age 20, 30 and 40. 
FIGURE 1 Estimates of the age-specific fertility rates of women aged 15-49 living in selected Latin American countries according to their conjugal situation, 1980-2010. (Continued).
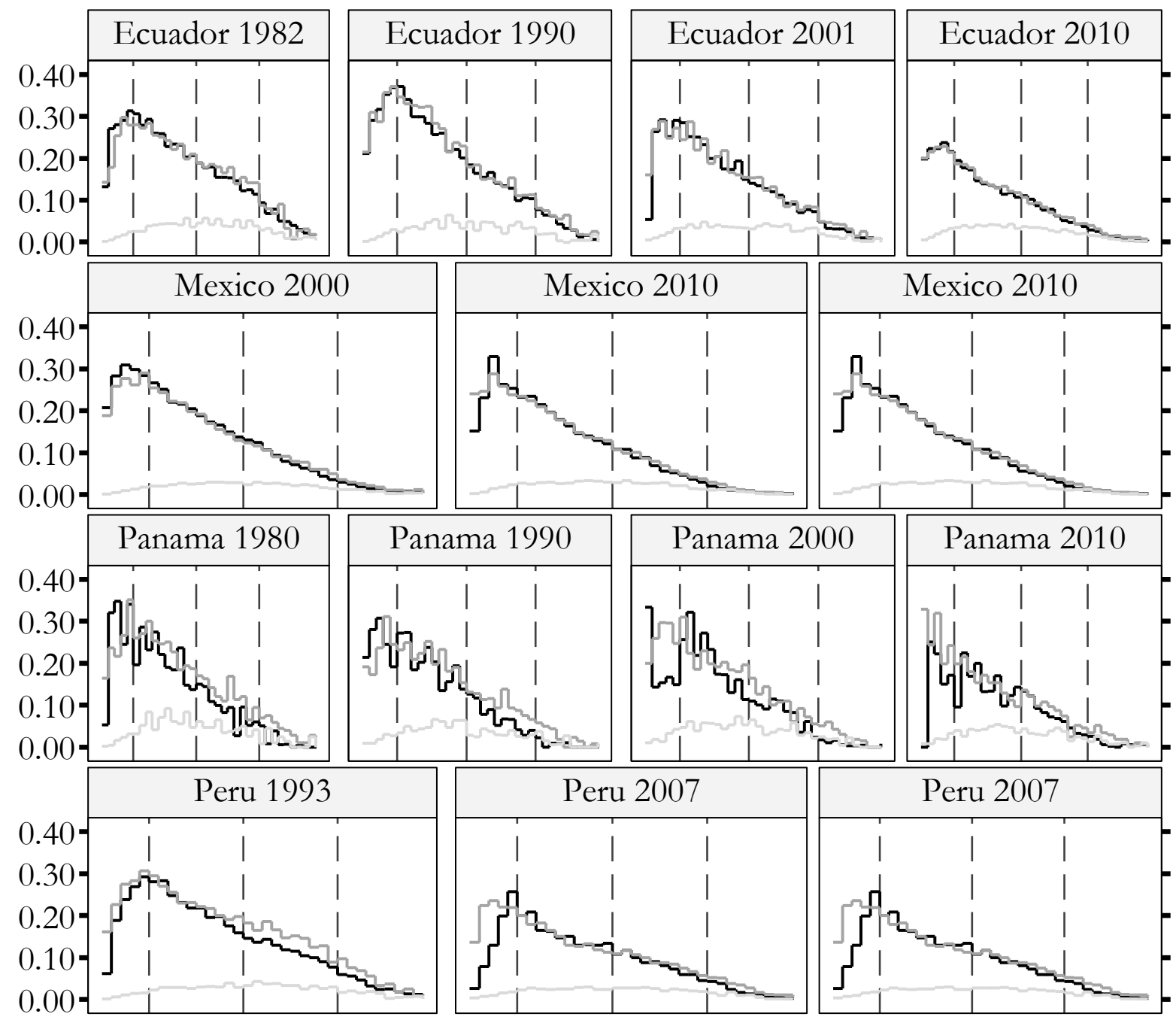

0.40
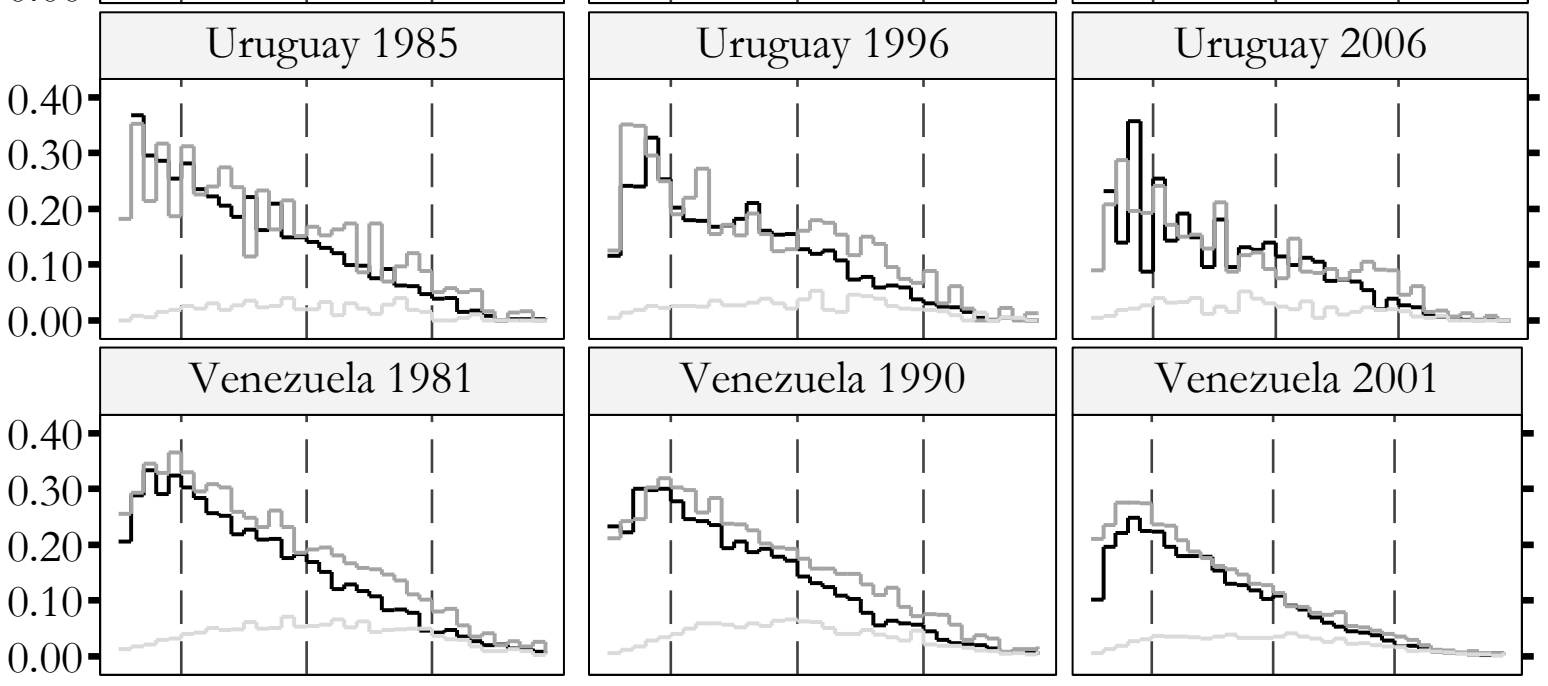

- Marriage $\quad$ Consensual union

Not in union

Source: Census data from IPUMS. Estimates from the own-children method. Vertical lines at age 20, 30 and 40. Values over 0.40 for Uruguay are not depicted. 
FIGURE 2 Point estimates and 95\% confidence interval of the total fertility rates of women aged 15-49 living in selected Latin American countries according to their conjugal situation, 1980-2010.
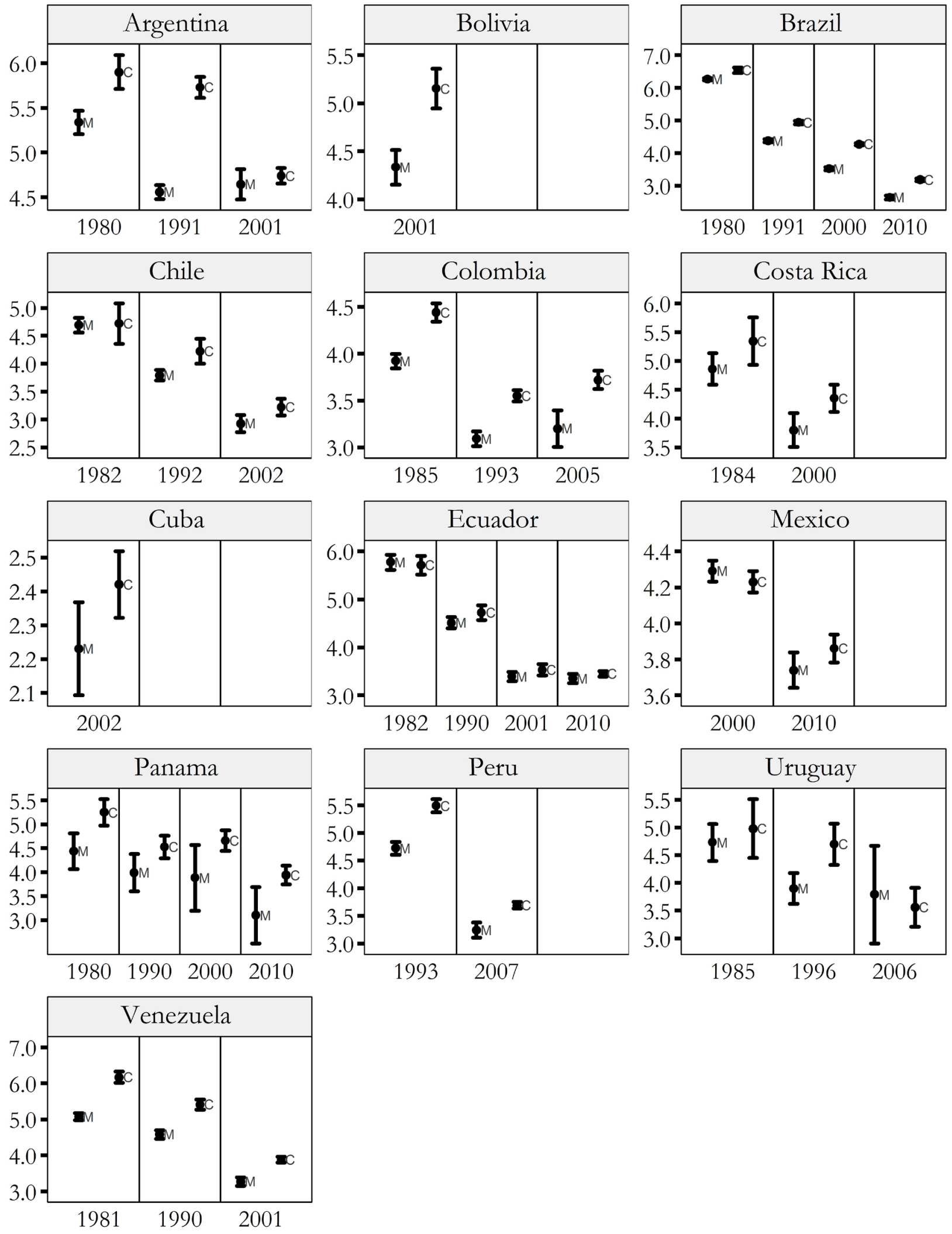

Source: Census data from IPUMS. Estimates from the own-children method and Poisson regression. 
FIGURE 3 Point estimates and 95\% confidence interval of the total fertility rate of women aged 15-49 living in selected Latin American countries according to education level by conjugal situation, 1980-2010.
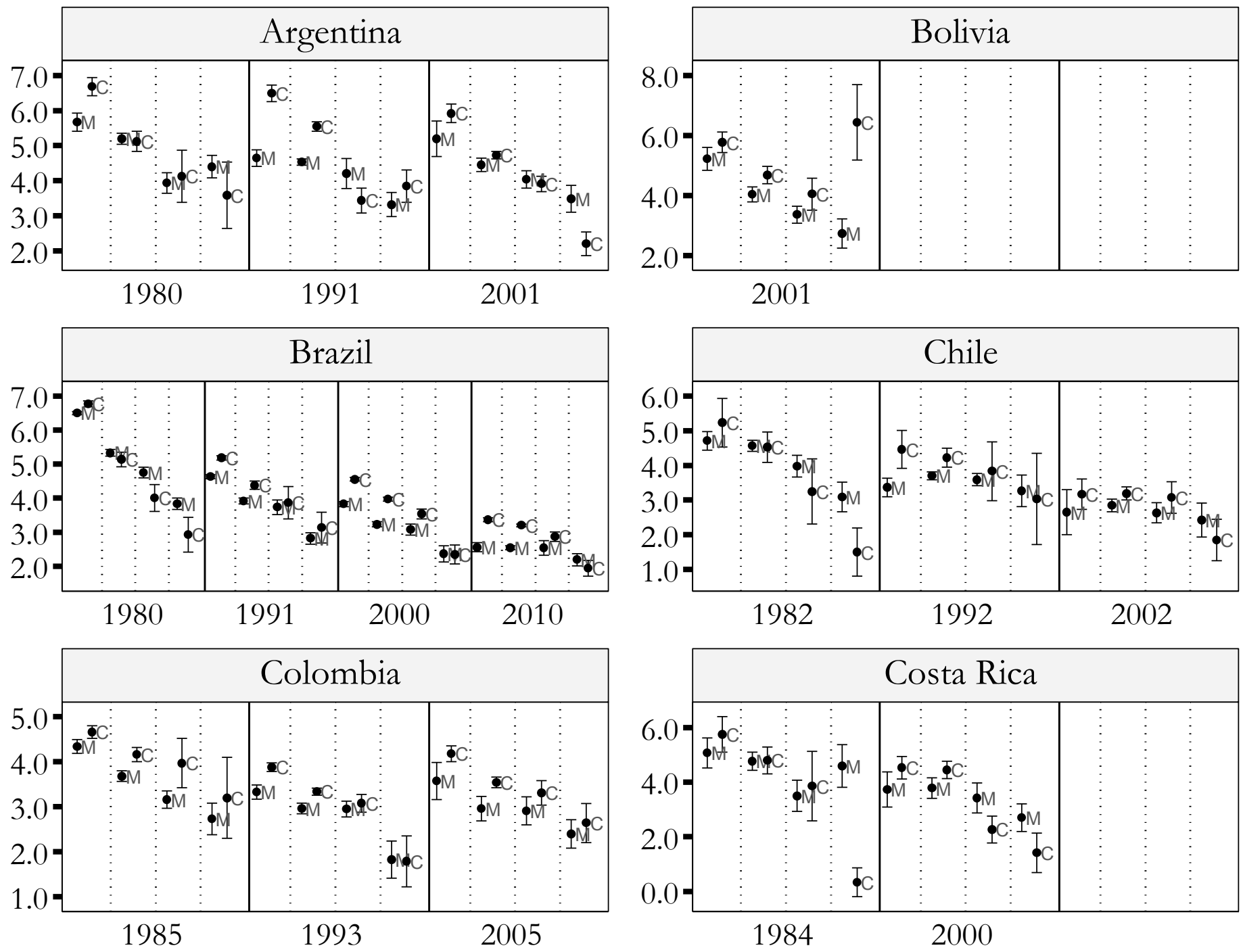

Source: Census data from IPUMS. Estimates from the own-children method and Poisson regression. From left to right, for each census, the education levels are less than primary completed, primary completed, secondary completed, and university completed. 
FIGURE 3 Point estimates and 95\% confidence interval of the total fertility rate of women aged 15-49 living in selected Latin American countries according to education level by conjugal situation, 1980-2010. (Continued).
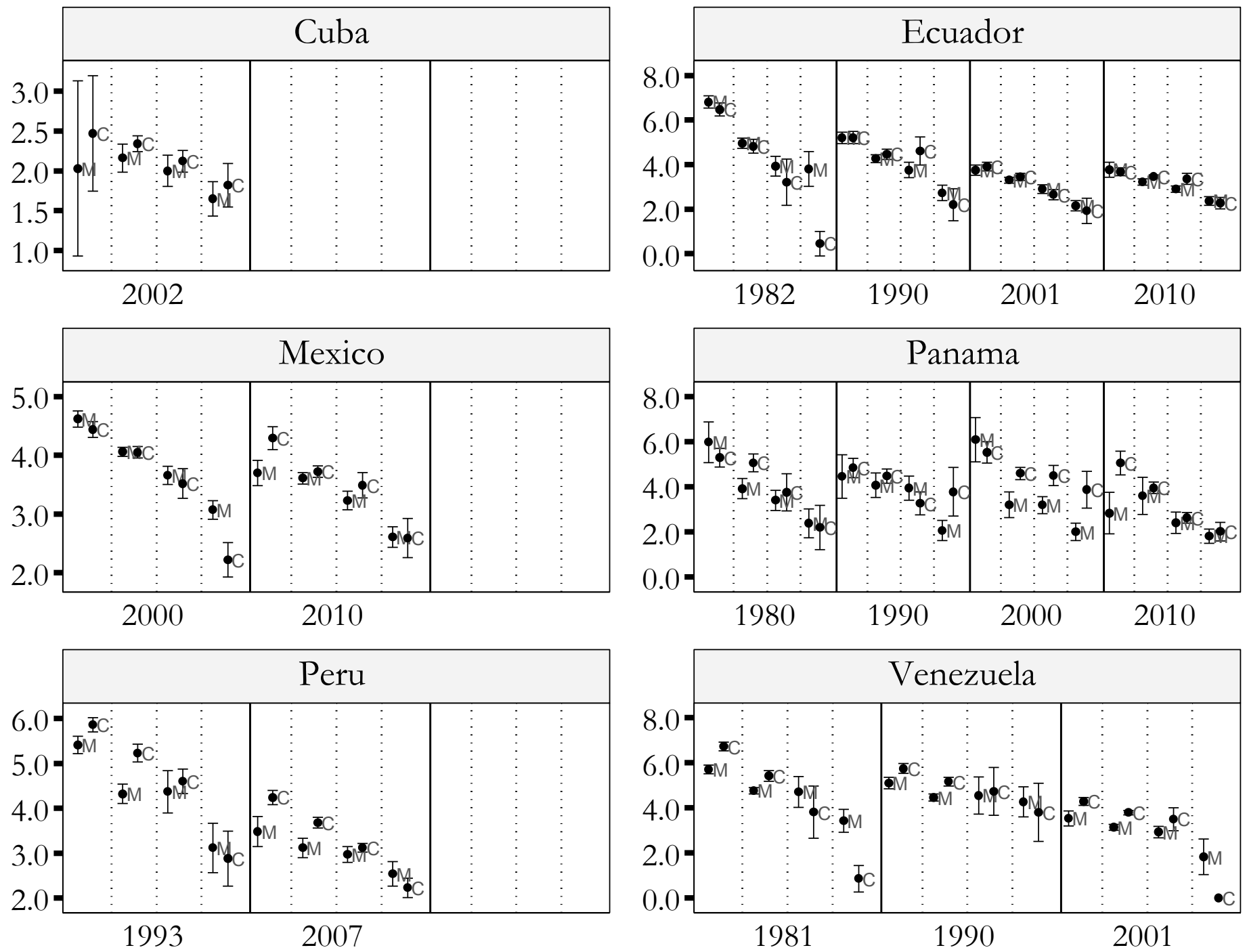

Source: Census data from IPUMS. Estimates from the own-children method and Poisson regression. From left to right, for each census, the education levels are less than primary completed, primary completed, secondary completed, and university completed. Uruguay is omitted from this figure because of inconsistent estimates in 2006. 